\title{
Place-based policies, firm productivity, and displacement effects: Evidence from Shenzhen, China
}

\author{
Hans R.A. Koster ${ }^{1,2}$ | Fang Fang Cheng ${ }^{3}$ | Michiel Gerritse ${ }^{4,5}$ (1) \\ Frank G. van Oort ${ }^{4,5,6}$
}

${ }^{1}$ Department of Spatial Economics, Vrije Universiteit Amsterdam, Amsterdam, The Netherlands

${ }^{2}$ The Centre for Economic Performance (Urban Programme) at the London School of Economics, National Research UniversityHigher School of Economics (Russian Federation), The Tinbergen Institute and the Centre for Economic Policy Research, Moscow, Russia

${ }^{3}$ Urban and Regional Research Centre, Utrecht University, Utrecht, The Netherlands ${ }^{4}$ Erasmus School of Economics, Erasmus University Rotterdam, Rotterdam, The Netherlands

${ }^{5}$ The Tinbergen Institute, Amsterdam, The Netherlands

${ }^{6}$ The Urban and Regional Research Centre, Utrecht University, Utrecht, The Netherlands

\section{Correspondence}

Hans R.A. Koster, Department of Spatial Economics, Vrije Universiteit Amsterdam, De Boelelaan 1105, 1081HV Amsterdam, The Netherlands.

Email: h.koster@vu.nl

\section{Funding information}

Nederlandse Organisatie voor Wetenschappelijk Onderzoek, Grant/Award Number: 451-14-034

\begin{abstract}
Developing and transitional countries devote considerable funds to selected areas to stimulate local growth and firm productivity. We examine the impact of place-based interventions due to the opening of science parks in Shenzhen, China, on firm productivity and factor use. Our identification strategy, exploiting spatial and temporal differencing in firmlevel data, addresses the issues that (a) the selection of science park locations is not random and (b) high-productivity firms sort themselves into science parks. Firm productivity is approximately $15-25 \%$ higher due to the science park policy. The policy also increases local wages and leads to distortions due to job displacement.
\end{abstract}

\section{KEYWORDS}

place-based policies, productivity, science parks, transitional economies

\section{JEL CLASSIFICATION}

H2, R3, R5 


\section{1 | INTRODUCTION}

Many governments spend considerable amounts of money to stimulate employment growth, fight unemployment, and spur productivity. These investments are often not space-neutral but differ between regions, cities, and even between neighborhoods within cities. In developed countries, place-based policies tend to focus on distressed regions or neighborhoods (Gobillon, Magnac, \& Selod, 2012). In the European Union, for example, the Regional Development Fund explicitly targets regions with high unemployment and a (nominal) income below $75 \%$ of the EU average. Similarly, in the United States, programs such as federal urban empowerment zones (EZs) and enterprise communities are designed to use grants and hiring credits to benefit lagging neighborhoods (see e.g., Busso et al., 2010). However, the effectiveness of place-based policies, as opposed to people- or firm-based policies, is debated.

The common rationale for both place-based and people-based (i.e., spatially blind) policies is to improve the prospects of poor and disadvantaged households (Barca, McCann, \& Rodríguez-Pose, 2012; Neumark \& Simpson, 2015). Place-based investments in lagging regions may be more effective in reaching deprived households than economy-wide investments (Garretsen, McCann, Martin, \& Tyler, 2013; McCann \& Ortega-Argilés, 2013). However, the focus on lagging regions may come at a (welfare) cost as the inefficiencies caused by place-based policies could be substantial. Glaeser (2008) provides several arguments against place-based policies. First, place-based policies that target deprived areas bring economic activity to the least productive places, thus lowering overall productivity. Second, productivity also falls if poor regional performance can be traced back to negative spillovers from local people or firms. Third, the distributional effects of placebased policies are unclear. For example, beneficiaries of the aid may be the richer people in the impacted area, thereby increasing inequalities within the region. Moreover, the spatial extent of the effects of place-based investments may be unpredictable, so choosing a scale for a place-based policy can be problematic (Cheshire, Nathan, \& Overman, 2014).

Whether place-based policies have large welfare costs depends on the responses of the people in the designated areas. Kline (2010) argues that place-based employment policies are most efficient when the demand and supply of labor are inelastic-in that case, the policy instrument produces only few distortions to behavior. Similarly, Busso, Gregory, and Kline (2013) show that a larger heterogeneity in workers' preferences regarding commuting and residential locations leads to fewer job changes and capitalization in wages instead of in land rents. Employment decisions and the degree to which workers and firms change location thus determine the welfare effects of the policies. As a result, the welfare costs or deadweight losses of such programs can be approximated by interpreting the local economy's responses to the program.

The empirical results on the effectiveness and the welfare costs of place-based policies are mixed (see for an overview Neumark \& Simpson, 2015). Most studies find that positive effects are offset by substantial displacement effects within adjacent localities, but virtually all of the empirical studies on place-based policies examine programs for deprived areas in developed countries. The welfare effects may be different when applied to place-based policies for leading areas in developing and transition economies. Policies stimulate relatively productive firms and people and foster positive spillovers rather than negative spillovers. While almost unstudied, China, India, Brazil, South Africa, Russia, and many other transition economies extensively apply place-based policies and special economic zones to promote development. A scarcity of data on productivity and employment creation is argued to hamper strong conclusions on place-based policies in these economies (Frick, Rodríguez-Pose, \& Wong, 2018). Recently though, difference-in-difference evidence on the establishment of Special Economic Zones in China suggests positive but heterogeneous effects on productivity (Alder, Shao, \& Zilibotti, 2016; Wang, 2013). Chaurey (2013) documents large employment and output effects associated with location-based tax incentives in India. Using historical and topographical variation in industrial park assignments, Zheng et al. (2017) document the emergence of edge cities around industrial parks, fueled by productivity- and consumption-spillovers. Hence, these limited number of studies on the effects of place-based policies in transitional economies suggest that the bulk of evidence obtained for developed countries may not hold outside those countries (Barca et al., 2012; Foray, 2015).

This paper investigates the economic impacts of substantial place-based investments in Shenzhen, China. In China, economic place-based policies were carried out primarily to promote foreign direct investment, technology transfers, 
and exports (Zeng, 2010). Science parks are an actively used policy-instrument in this. Firms in science parks are expected to co-operate and interact more intensively with foreign investors and among themselves by locating in close proximity to each other. In other words, place-based investments aim to foster agglomeration economies and innovation within science parks. Moreover, in Shenzhen's science parks, land property rights are guaranteed, there is better access to fast internet, and different financial incentives are available for innovative firms (Cheng, Van oort, Geertman, \& Hooimeijer, 2014). More information on the exact incentives will be given in Section 3. In China, the number of science parks has increased dramatically in the last decade, which demonstrates the strong belief in the effectiveness of these policies (Cheng et al., 2014; Yeung, Lee, \& Kee, 2009; Zeng, 2010). Yet, with many economic, social, and institutional characteristics differing from those in Western economies, the economic impacts of science-parks in China and other developing countries are highly doubted and even called "pipedreams" (MacDonald \& Deng, 2004; Rodríguez-Pose \& Hardy, 2014). On the other hand, especially the case of the Special Economic Zone of Shenzhen (Southern China) and its related clusters and science parks receives attention in debates-it is the prime example of place-based development policies with positive effects on internationalization, growth, and innovation (Wei, 2000).

Empirical research on science parks and place-based development initiatives remains largely qualitative and rather anecdotal in character. For instance, all SEZs and science park initiatives discussed in overviews by Yeung et al. (2009), Zeng (2010), and Lai and Shyu (2005) base outcomes on Porter-style cluster analysis of concentration and survey-based evidence. Those results may be less representative for the welfare effects of place-based policies (Hu, Han, Yeh, \& Lu, 2010). Systematic quantitative research supporting or questioning place-based science park policies and its impacts on firm performance is largely lacking.

We use data on manufacturing industries in the Shenzhen metropolitan area to investigate the impact of science parks on firm productivity. We use data on approximately 10,000 firms in the Shenzhen area for a 10-year period that covers the opening of different science parks. For each firm we have information on output, workforce size, capital stock, and wages. The data also provide information on the location of the firms at the neighborhood level, and a number of other firm characteristics.

Our analysis contributes to the literature in the following ways. First, it complements the limited knowledge of the effects of place-based strategies, by considering science parks in Shenzhen an economically advanced location in China. Exploiting microdata to identify the causal impact of the policy, we extend the scarce results on the effectiveness of place-based policies in leading areas in transitional countries. To interpret our estimates, we also develop a theoretical framework of the impact of science park policies. In the Chinese setting, there is little information on the exact use of different instruments, and more standard methods of evaluation do not apply. Using our estimates in a "sufficient statistics" approach (Chetty, 2009), we derive an assessment of the relative size of the productivity effects and the deadweight losses from the policy.

As a second contribution, the paper aims to identify the causal impacts of a place-based development program. Just comparing firm performance inside and outside the area of a program does not yield an accurate evaluation of the program's impact. Often, governments single out specific locations for grants or to establish Special Economic Zones. Moreover, once a place-based policy is initiated, productive firms and workers may sort into these areas because they benefit from the policy or because the policy applies specifically to them. Ignoring the selection of a policy area and the sorting processes in the evaluation of a place-based policy may lead to biased estimates of the true policy effects. To identify a causal effect of the science park policy, we need to control for unobserved locational traits and trends because science parks may have innate attractive geographic features and may evolve differently from nontargeted areas. To control for unobserved locational endowments, we rely on spatial differencing. This approach implies that we compare firms inside science parks to firms in areas that are very close to science parks-those areas are very similar in geographical and functional characteristics. Hence, conditional on selecting areas very close to a science park boundary, the exact location of the boundary is considered to be random. We relax this assumption by including flexible functions of distance to the nearest science park boundary or geographic co-ordinates. To address the issue that highly productive firms may sort themselves into science parks, for example, because of entry requirements, we exploit the panel nature of our data and include firm fixed effects. Hence, using the fact that not all science parks opened up at the same time, we 
identify the effect of science parks by comparing productivity differences before and after the opening of a science park for a firm located in a science park vis-à-vis a firm that is located just outside a science park. A potential worry with this approach is that if the science park leads to local displacements, the estimated productivity effects might be overstated. To address that possibility, we also consider an alternative identification strategy as a robustness check, based on the observation that local industrial parks are often promoted to science parks later on, making them a feasible control group.

Our results show that area-based incentives have a substantial impact on the productivity of firms in the Shenzhen science parks. Firm output increases by $15-25 \%$ due to science park policies, even after ruling out alternative explanations of sorting and selection by means of firm fixed effects and spatial differencing,. These large and economically meaningful effects are in line with the findings of Wang (2013) and are consistent with the idea that place-based policies have more sizable effects in transition economies. We furthermore show that local wages have increased by approximately $10-15 \%$, which is smaller than the relative change in firm productivity. We also show that large productivity improvements are paired with distortive effects. Workforce size increases in science parks, which suggests a job displacement effect. Given the assumptions of our theoretical model, we estimate that the deadweight loss due to these displacement effects is sizeable (about $10-40 \%$ of the productivity benefits). The displacement of capital has far lower welfare consequences. We subject our results to an extensive sensitivity analysis, including an analysis based on another (cross-sectional) data set.

The remainder of the paper is organized as follows. In Section 2, we outline our theoretical framework and derive conditions under which we can approximate a deadweight loss of science park policies. Section 3 discusses the regional context and the data. In Section 4, we outline our empirical strategy. Section 5 presents the main results for productivity, wages, employment, and capital stock. Using these estimates and the structure of the theoretical model, we estimate the deadweight loss associated with these policies. In Section 6, we provide a summary of an extensive sensitivity analysis, which is discussed in detail in Online Appendix C. Section 7 concludes.

\section{2 | THEORETICAL FRAMEWORK: PLACE-BASED POLICIES AND DEADWEIGHT LOSSES}

We first discuss the potential theoretical welfare effects of place-based policies. The intuition follows Kline (2010), Kline and Moretti (2013), and Busso et al. (2013) and helps to interpret our empirical results as "sufficient statistics"-allowing inferences on welfare using estimated elasticities (Chetty, 2009). Our approach is more parsimonious than related structural models because we rely on spatial differencing to identify policy effects. Comparing firms that are at very short distances from each other implies that a worker's residential decision does not vary much between the compared working locations. The design thus circumvents the issue that consumption amenities affect labor supply decisions and the issue that we do not observe such amenities. We assume that placebased policies (i.e., setting up a science park) involve a bundle of instruments: they may directly affect productivity via an increased technology level (e.g., availability of broadband internet) and stimulate the use of capital and labor. ${ }^{1}$ In our data, we cannot observe the different elements of the program, but we show that with minimal information, one may still obtain an estimate of the relative size of the productivity effects and the deadweight losses from the policy.

We assume that there are two locations, $z=1,2$. The science park policy only targets location 1 . Firms in both locations employ labor and capital to produce a numéraire consumption good. Capital is hired from a "large"

\footnotetext{
${ }^{1}$ Zeng (2015) provides a discussion on advantages of Special Economic Zones in China and science parks within these Special Economic Zones. He lists the following advantages: An efficient administrative system (no red tape), good physical and digital infrastructure, fiscal and nonfiscal firm (and FDI) level incentives, reduced corporate tax rates, provision of research funding, education subsidies of employees, economic autonomy and special municipal laws and regulations, technology learning programmes, an innovative culture, zone management, and locational advantages (like proximity to airports, universities and Hong Kong in the case of Shenzhen). Three disadvantages are listed as well: the risk of environmental degradation, risk of unbalance of industrial and social development, and copying mushroom behaviour by local authorities when the market already may be saturated.
} 
competitive financial market where firms (re-)finance capital at a competitive rate. Workers and owners of capital consume the numéraire good and workers can choose where to work, supplying labor to firms in one of the two locations. A worker's utility $u_{i z}$ is equal to the consumption of the numéraire good and a worker-specific heterogeneity term:

$$
u_{i z}=c_{i}+\xi_{i z}
$$

The worker's heterogeneity term $\xi_{i z}$ depends on the location $z$ in which the worker is used. This dependence of location allows for preferences for the worker's job location, apart from the wage. As we compare firms at the boundaries of science parks, it is unlikely that $\xi_{i z}$ captures differences in preferences for commuting and geographic attributes. Instead, differences in $\xi_{\text {iz }}$ may be explained by a required mastery of English, administrative skills, levels of workplace stress, preferences for specific types of companies (international and high-tech), or prestige. For the purpose of the welfare analysis, we are agnostic about how exactly these preferences take form.

The production function of a firm $j$ depends on labor $\ell_{\mathrm{jz}}$, capital $k_{\mathrm{jz}}$, location-specific technology constant $A_{z}$ and a firm-specific heterogeneity term $\omega_{j}$. Firm productivity is thus a composite of an individual technology term and a location-specific productivity shifter. The total production is: $a_{j z}=q\left(A_{z}, \ell_{j z}, k_{j z}, \omega_{j}\right)$, so profit is given by:

$$
\max _{\ell, k} \pi_{\mathrm{jz}}=q_{\mathrm{jz}}-w_{\mathrm{z}}\left(1-t_{\mathrm{z}}\right) l_{\mathrm{jz}}-r\left(1-s_{\mathrm{z}}\right) \mathrm{k}_{\mathrm{jz}}
$$

where we allow for any explicit or implicit subsidies to the employment of labor $\left(t_{z}\right)$ or capital $\left(s_{z}\right)$. The first-order condition of the profit-maximization implies that $\mathrm{d} q_{j z d} / \mathrm{d} \ell_{j z}=w_{z}\left(1-t_{z}\right)$ so that the wage of a worker is determined by his marginal productivity, corrected for the subsidy.

The place-based policy has two impacts for a firm in region 1. First, the policy can affect the technology in location $1\left(A_{1}\right)$, leading to changes in firm productivity. We assume that the individual firm productivity term $\omega_{j}$ and the location-specific technology term $A_{z}$ are log-separable. This assumption implies that locationspecific productivity shocks affect the log productivity of efficient and inefficient firms in the same way. Second, the policy can entail subsidies to factor employment at costs $t_{1} w_{1} L_{1}$ and $s_{1} r K_{1}$, where $L_{1}=\int_{j \in z=1} l_{j} d j$ and $K_{1}=\int_{j \in z=1} k_{j} d j$ are the cumulative factor uses for location 1 . Because there are no policies in location 2, it holds that $t_{2}=s_{2}=0$.

The total costs of the productivity improvements are captured in a required central government budget for science parks $T_{1}=T\left(A_{1}, Q_{1}\right)$, where $Q_{1}=\int q_{j 1} d j$ is the aggregate production in location 1 . Note that a higher technology level $A_{1}$ requires a higher budget. The term $Q_{1}$ enters because given a level of productivity, higher production could imply a larger required budget: for example, if firms enter or expand production, more broadband investment could be required to maintain the same level of technology. If technology inputs are nonrival, a higher level of production $Q_{1}$ implies that a higher budget is needed to achieve the same productivity level $A_{1}$.

The welfare function is the sum of individual utilities, firm profits, capital earnings, and the net government budget. Consumers' wages equal their consumption of the numéraire. Thus, the welfare function is given by:

$$
W=\int\left(w_{i z}+\xi_{i z}\right) d i+\int \pi_{j z} d j+r\left(K_{1}+K_{2}\right)-\int_{j \in z=1} t_{1} w_{1} l_{j} d j-\int_{j \in z=1} s_{1} r k_{j} d j-T\left(Q_{1}, A_{1}\right)
$$

where $j \in z=1$ pertains to firms in location 1 . The place-based policy causes direct productivity improvements (via the technology level) and changes in labor and capital levels. The costs of the policy are the implicit or explicit subsidies given to capital and labor and the costs of increasing the overall productivity level. Let us denote the application of the place-based policy by the variable $p_{1}$.

Using the welfare function, we can study the welfare effects of the science park policy. We differentiate the welfare function with respect to $p_{1}$, assuming that $p_{1}$ also affects the labor and capital subsidies. On the capital and labor market 
we use that wage and rental rate changes and subsidy transfers are welfare neutral, and we use the neutrality of the profit function with respect to factor employment, from the envelope theorem. Using these, the welfare effect is:

$$
\frac{\mathrm{d} W}{\mathrm{~d} p_{1}}=\frac{\partial Q_{1}}{\partial A_{1}} \frac{\mathrm{d} A_{1}}{\mathrm{~d} p_{1}}-\left(\frac{\partial T_{1}}{\partial A_{1}}+\frac{\partial T_{1}}{\partial Q_{1}} \frac{\partial Q_{1}}{\partial A_{1}}\right) \frac{d A_{1}}{d p_{1}}-t_{1} w_{1} \frac{d L_{1}}{d t_{1}} \frac{d t_{1}}{d p_{1}}-s_{1} r_{1} \frac{d K}{d s_{1}} \frac{d s_{1}}{d p_{1}}
$$

The first term in Equation (3) is the direct increase in production due to the science park policy through its increase in firm productivity, which accounts for the direct effect on production net of any increases in factor employment. In Section 5.1, we estimate this effect using microdata while controlling for changes in production factor usage. The second term in Equation (3) is the composite effect on the required budget $T_{1}$. Increasing the technology level comes at the direct cost of increasing the budget. Indirectly, increased productivity might lead to higher production levels, which in turn could raise the budget; this second-order effect is captured in the second term $\left(\partial T_{1} / \partial Q_{1}\right)\left(\partial Q_{1} / \partial A_{1}\right)$.

The third term denotes the labor market effect of the policy: $t_{1} w_{1}\left(d L_{1} / d t_{1}\right)\left(d t_{1} / d p_{1}\right)$. The welfare effects of changes in the workforce are considerably simplified by noting that a marginally affected worker is indifferent to working in the science park or not: possible wage differences are exactly reflected in his preference for locations $\xi_{\mathrm{iz}}{ }^{2}$ Using this notion, the welfare loss from labor reallocation is the (implicit) subsidy, multiplied by the number of workers that are displaced. Intuitively, if workers do not move, the policy is simply a transfer of which the net effect on welfare is zero. Welfare losses arise only if workers move after the subsidy: some workers prefer not to work in location 1 but are induced to do so by the labor subsidy. The degree to which science park policies subsidize labor is left implicit in the term $\mathrm{dt}_{1} / \mathrm{dp} p_{1}$ because in our empirical application, we do not know the actual rate of subsidies. The elasticity of labor supply is important in determining the deadweight losses of the policy. To provide a supplementary empirical analysis of the labor supply responses, we investigate the wage responses to the policy in Section 5.2. Note that although the wage responses are not present in the welfare effects, they are not ruled out by the theoretical model; changes in wages without changes in allocation are simply a welfare-neutral transfer.

The capital market is similarly affected by the place-based policy, as the fourth term in Equation (3) illustrates: $s_{1} r_{1}\left(d K / d s_{1}\right)\left(d s_{1} / d p_{1}\right)$. Similar to the labor-market-related policies, the welfare losses crucially depend on the capital mobility response. Intuitively, if capital does not move, the subsidy is simply a loss to the government offset by a gain to the capital owner. If capital moves, the subsidy compensates the higher productivity that capital could have achieved in another location.

We can obtain an indication of the relative size of the deadweight losses associated with the place-based policy that allows for a comparison of the direct benefits (in terms of changes in the technology level) with the deadweight losses of the factor employment responses. The sum of the welfare effects is the direct productivity effect, the deadweight losses due to factor employment changes, and the financing costs of the productivity effects (all of which are incorporated in Equation (3)). We assume that the labor and capital-related policies change with the science park status, so $\mathrm{dt}_{1} / \mathrm{d} p_{1}$ and $\mathrm{ds}_{1} / \mathrm{d} p_{1}$ may be nonzero. The employment responses can then be written into elasticities: multiplying and dividing the welfare loss from labor reallocation by $L_{1}$ gives $-L_{1} w_{1} e_{\ell}$, where $e_{\ell}$ is the elasticity of labor supply with respect to the science park policies. Next, the term $L_{1} w_{1}$ can be written as a cost share of production, $\alpha_{\ell} Q_{1}$. Rewriting the capital response in the same way and factoring the level of production $Q_{1}$, the net welfare effect $\Delta W$ can be written as:

$$
\Delta W=Q_{1}(\Delta \mathcal{R} W)-\left(\frac{\partial T_{1}}{\partial A_{1}}+\frac{\partial T_{1}}{\partial Q_{1}} \frac{\partial Q_{1}}{\partial A_{1}}\right)
$$

\footnotetext{
${ }^{2}$ The incentives to change job location can, of course, be restricted to wages by assuming zero heterogeneous preferences for location of work. This special case yields very stark theoretical welfare conclusions (see, for instance, Busso et al., 2013) but does not change our empirical welfare results.
} 
with:

$$
\Delta \mathcal{R} W=e_{A} \frac{\mathrm{d} A_{1} / \mathrm{d} p_{1}}{A_{1}}-\alpha_{l} e_{1} \frac{\mathrm{d} t_{1}}{\mathrm{~d} p_{1}}-\alpha_{k} e_{k} \frac{\mathrm{d} s_{1}}{\mathrm{~d} p_{1}}
$$

where we refer to $\Delta \mathcal{R} W$ as the gross relative welfare effect, $e_{A}$ is the direct semielasticity of production to the science park policies (via productivity), and $e_{\ell}=\frac{t_{1}}{L_{1}} \frac{d L_{1}}{d t_{1}}$ and $e_{k}=\frac{s_{1}}{K_{1}} \frac{d K_{1}}{d s_{1}}$ are the elasticities of labor and capital employment to the science park policies. By formulating the welfare effects as elasticities weighed by shares of production, the separate effect of each welfare gain and loss can be compared at a common scale-the output level. This approach does not allow us to derive absolute levels of welfare losses, but it does allow us to compare the direct productivity benefits to the loss due to labor (or capital) reallocation per unit of output. Thus, the welfare losses are interpreted relative to the productivity increases in percentages of output. The term $e_{A}\left(\mathrm{~d} A_{1} / \mathrm{d} p_{1}\right) / A_{1}$ represents the percentage increase in output due to science park policies, keeping capital and labor constant-this term, therefore, represents the partial effect due to changes in the technology constant. This direct effect is estimated in Section 5.1. The magnitude of the deadweight loss crucially depends on whether the place-based policy leads to changes in factor employment. Therefore, we estimate the effect of the science park on factor usage in addition to its effects on productivity in Section 5.3. The labor and capital responses to the place-based policy are weighted with the cost shares $\alpha_{\ell}$ and $\alpha_{k}$. The cost shares can be recovered by estimating a Cobb-Douglas production function, which we estimate in Section 5.1. Using the cost shares, the productivity gains and the factor movement deadweight losses are measured in terms of output, which allows us to compare the two quantities.

Intuitively, a high employment elasticity $e_{\ell}$ points to large deadweight losses, because the policy has strong displacement effects. If labor costs shares in production $\left(\alpha_{\ell}\right)$ are higher, distortions on the labor market lead to larger welfare losses, because they affect larger shares of production. In Section 5.3, we put the productivity effects and factor employment changes together to present an estimate of the relative size of the deadweight losses. Note that the last term in Equation (4) represents the costs of public funds, which are unknown in our application, so we will only be able to measure the gross relative welfare effect.

One may argue that agglomeration effects drift across science park boundaries. In principle, this would lead to an underestimate of the productivity effects because firms outside but close to the science park may still benefit from agglomeration benefits generated inside the science park. However, in Online Appendix C.3 we show that agglomeration economies drifting across the boundary are unlikely to affect the results in our setting. We have therefore relegated the discussion of agglomeration effects in the theoretical model to Appendix A.1.

Our model assumes that there is one type of labor. Allowing for more types of labor yields a similar expression for distortions-we also explore that in Appendix A.2. The framework also does not consider residential land use. In principle, this could represent another displacement effect, next to the job displacement effect considered here, thus leading us to underestimate the total distortions caused by the science park policy. We leave residential land use out of our discussion as (a) workers' residential choices are not available in our data and (b) we identify impacts from the comparison of firms very near one another, so that a worker does not have to change residence to change jobs.

This stylized model also does not consider land use. Firms may individually change land consumption, but the designated science park land is in fixed supply. Moreover, the land is ultimately government owned. Thus, without changes in land supply (and the government effectively subsidizing its own land), land market policies have no welfare effects in our model. Data on land use are only available for a subset of firms in our data set. In Online Appendix C.4, we investigate whether this limitation impacts our main conclusions. 


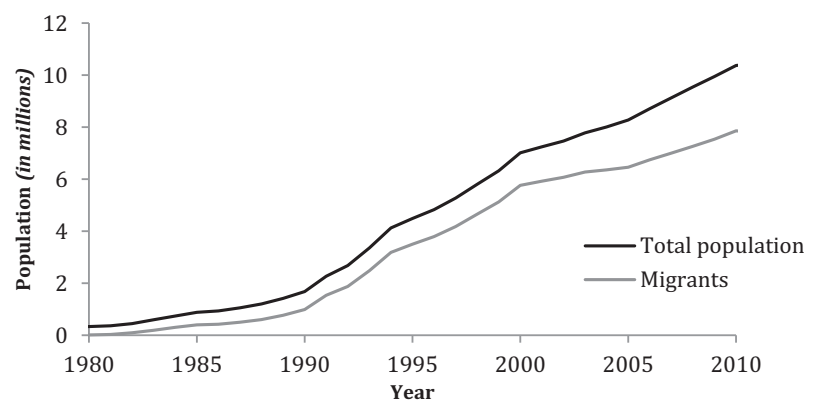

FIGURE 1 Population and migrants in Shenzhen since 1980

\section{3 | REGIONAL CONTEXT AND DATA}

\section{1 | Regional context}

Shenzhen is considered one of the most important high-tech hubs in China. It was originally established as one of four special economic zones (SEZs) in 1979 to operate a socialist market economy because of its proximity to Hong Kong, which had been facing increasing pressure from rising labor costs and a tight land supply since the $1970 \mathrm{~s}$. Initially, the SEZs were geographically isolated but economically open areas where special and flexible economic policies were carried out, primarily to promote foreign direct investment, technology transfers, and exports. The special treatment of these areas coevolved with high economic and population growth rates. Figure 1 shows that the population of Shenzhen increased from a mere 310 thousand in 1980 to almost 11 million in 2010. A large proportion of the residents are migrants (more than $70 \%){ }^{3}$ Shenzhen received a substantial inflow of industrial activities from Hong Kong after the border was opened, most of which are low-tech and medium-tech manufacturing activities such as parts assembly (Enright, Scott, \& Chang, 2005). Compared with their foreign counterparts, Shenzhen's manufacturing firms have relatively thin profit margins that have been further eroded by rising land and labor costs in recent years (Linden, Kenneth, \& Dedrick, 2009; Shenzhen Planning Bureau, 2006).

Not long after the launch of the SEZs, the zones began to be emulated throughout China to foster economic growth and promote innovation. The concept was appealing because cities and regions could cordon off limited areas to offer special incentives to foreign and later also to domestic investors (Wu \& Gaubatz, 2013, p. 115). The next wave of zones was in the form of science parks, also called high-tech zones. In these areas, research institutions and firms are expected to co-operate and interact by locating in close proximity to each other. Some policies target more conventional manufacturing firms, while others promote high-tech enterprises and business services.

In Shenzhen, officials also implemented a strategy to develop science parks. The policy was designed to attract high-tech industries, stimulate innovation and foster entrepreneurship ( $\mathrm{Ng}, 2003$; Shenzhen Bureau of Trade \& Industry, 2001). The first high-tech science park in China, the "Shenzhen Science Park" (Shenzhen Keji Yuan, known as the Shenzhen High-tech Industrial park [SHIP] today) was established in 1985. It was selected and certified as one of the first six national-level science parks in China in 1996. In addition, in 1998, the Shenzhen municipal government issued a policy document with regulations to further support the growth and development of high-tech

${ }^{3}$ Migrants are defined as residents that are not "Hukou" holders. Hukou is a registration system of residents and can be granted to migrants when certain requirements are met. Hukou holders enjoy greater social security rights than non-Hukou holders. 

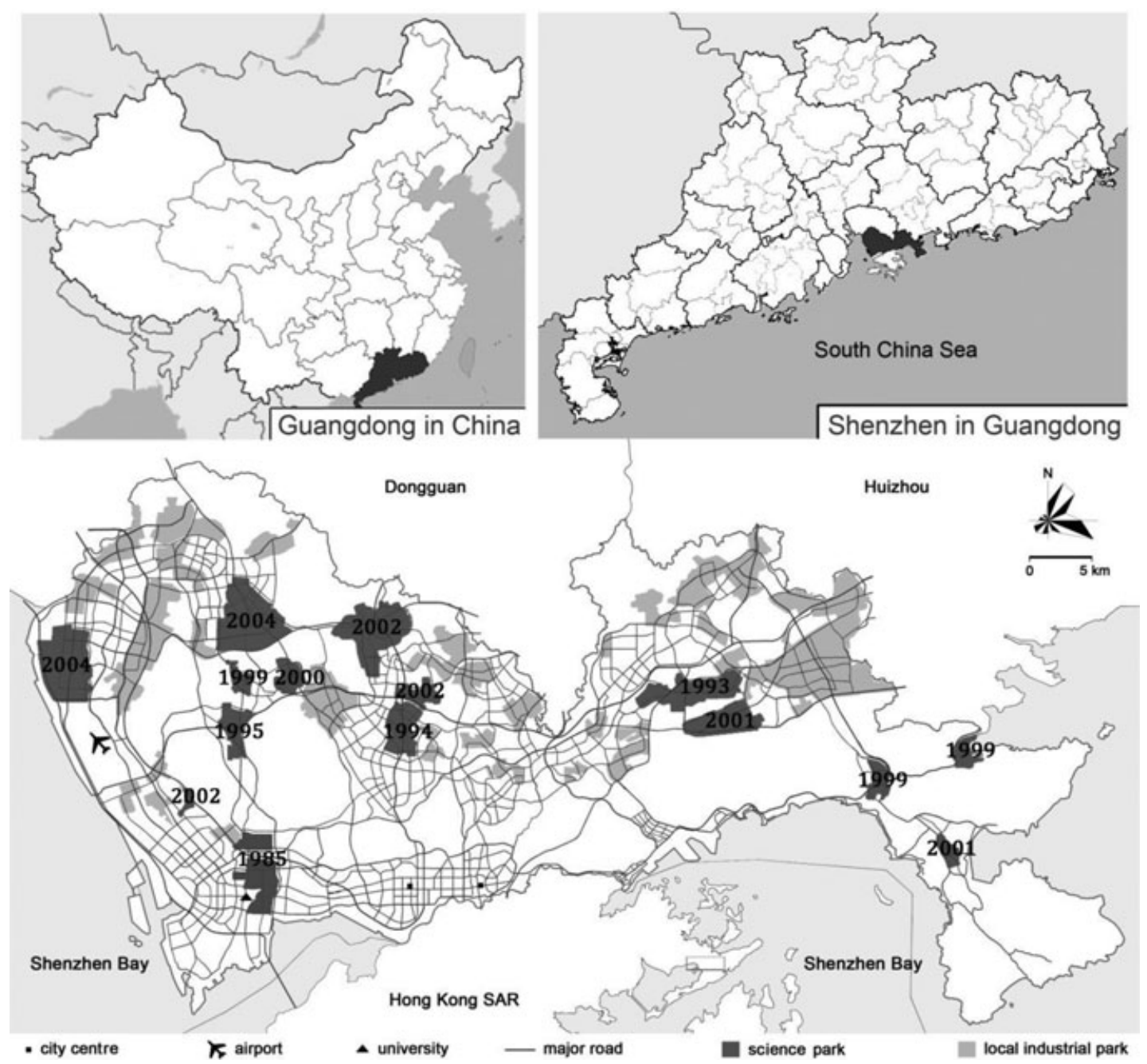

FIGURE 2 Geographic distribution of science parks in the Shenzhen area

industries. This document includes a package of preferential policies that apply exclusively to firms in science parks (Cheng et al., 2014). First, firms in these areas are offered a streamlined channel to government agencies that guarantees their ability to obtain more efficient services from the government. Second, science park agencies provide services in terms of financing, management, administration, and marketing. Third, firms in science parks also have easier access to start-up funds and to a special fund that was exclusively established for science and technology firms in science parks (Keji Sanxiang Jingfei). This fund provides 10 million yuan (approximately $\$ 1.5$ million) each year to returned-from-overseas Chinese start-ups and 20 million yuan for R\&D activities. Firms engaged in high-tech activities in science parks can receive R\&D subsidies in amounts equivalent to $3-10 \%$ of their total sales. Fourth, facilities such as banks, schools, restaurants, post offices, meeting places, and supermarkets are offered in the science parks. Fifth, land policies are different inside science parks. Although all land in China is formally state-owned, firms in science parks typically enjoy exemptions from land use fees and other fees related to land leases. They are also exempt from property taxes for self-built or purchased properties for 5 years following start-up. 
The Shenzhen municipal government's policies have led to competition among the high-tech parks within the city (Cheng et al., 2014; Zeng, 2015). In 1997, Shenzhen had four science parks. By 2007 this number increased to 15 (see Figure 2, in which opening years are reported). In addition, existing local industrial parks and other agglomerations may be upgraded in the future to science parks. The rationale is that by improving the economic conditions, developing market-based institutions and providing financial capital and subsidies to firms in science parks, the firms will be more likely to invest in physical and human capital, which will in turn lead to innovations and sustainable economic growth. Possibly as a result of these preferential policies, the Shenzhen region has seen a rapidly increasing number of high-tech firms since 2000.

\section{2 | Data and variables}

The establishment-level data are acquired from the Chinese Industrial Statistics Database. This database is maintained by the Chinese National Statistical Bureau through compulsory registration and an annual firm survey collected by lower level statistical bureaus. The survey provides information on manufacturing firms. In total, there are over 3 million firm records over the period from 1998 to 2009 . The database that we use in this paper only includes firms with annual turnover exceeding 5 million yuan (approximately 0.8 million USD). Although only larger firms are included, any selection bias is expected to be small because the target population for the survey consists of companies that generate more than $90 \%$ of China's total industrial output. In this study, we have data on firms located in the Shenzhen area for the years 1998, 1999, 2001, 2004, 2006, and 2007. After excluding unreliable observations (e.g., with negative or zero output, which is less than 5\%), we obtain 22,535 observations on 9,345 firms. Firms are not necessarily present in all years because they may have been too small in certain years, went out of business or relocated to areas outside Shenzhen.

The data provide information on firm location and the most important firm characteristics, such as fixed assets (capital), employment, and taxes. Using the year of establishment, we calculate the firm's age and determine whether a firm is a start-up. We also have information on ownership status. Specifically, we know whether a firm owned by the state, by a private party, by another firm from Hong Kong, Taiwan, or Macau (HTM), or by a foreign owner. Because we are uncertain whether state-owned firms have an incentive to maximize profits, we exclude them from the analysis (only $2 \%$ of the observations). Of the total observations, $2.2 \%$ relate to firms with multiple establishments. Because we are not sure whether these other establishments are located in other zones, we drop them from our data set. ${ }^{4}$

To control for the effect of spatial factors that may impact firm productivity, we use spatial differencing: we compare firms that are close to science park boundaries. To make the identification strategy more convincing, we collect additional data from the 2007 Land Use Survey conducted by the Shenzhen Planning Bureau. We calculate the distance from the centroid of each neighborhood to the nearest employment center, airport, seaport, and the nearest highway ramp to control for accessibility. Additionally, we include a dummy variable that indicates whether a firm is located in the Special Economic Zone (SEZ), where preferential policies applied to firms in our period of analysis. ${ }^{5}$ Zoning has also been taken into account. In Shenzhen, strict land use regulations prohibit firms from locating in restricted zones, such as ecological protection zones, water reservoirs, and areas near polluting production facilities and the nuclear power plant.

We have information on the location of firms at the neighborhood level (shequ in Chinese). Neighborhoods are generally quite small $\left(3.16 \mathrm{~km}^{2}\right.$ on average), so a science park usually consists of multiple neighborhoods. ${ }^{6}$ The science $^{2}$ park boundaries do not necessarily match the neighborhood boundaries. However, the boundaries are sometimes arbitrarily close to the neighborhood boundaries, and sometimes no firms are located in the remainder of the

\footnotetext{
${ }^{4}$ However, including those observations will not change the results.

${ }^{5}$ Since the 1990 s, preferential policies in the SEZ have gradually been suspended. The last and most important policy, that firms in the Shenzhen SEZ enjoy a tax rate of $15 \%$, compared with $33 \%$ elsewhere, was suspended in 2008 .

${ }^{6}$ These neighborhoods are approximately twice the area of a census block in the United States (which is on average approximately $1.12 \mathrm{~km}{ }^{2}$ ).
} 


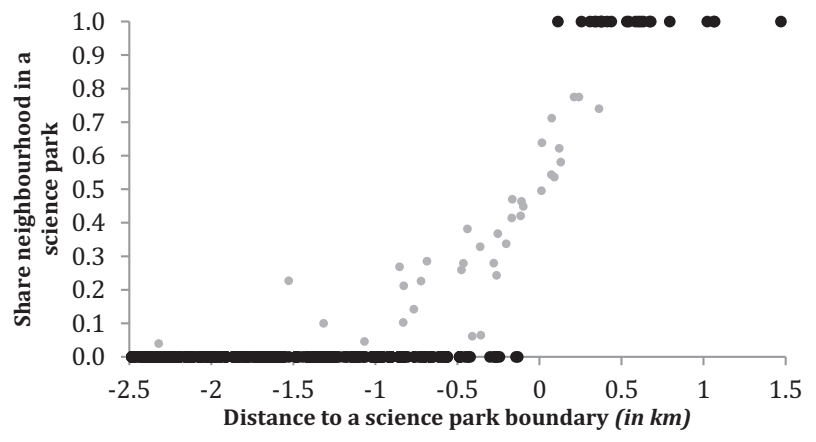

FIGURE 3 Average distance of the neighborhood to the science park boundary

neighborhood (e.g., because it is a restricted zone). We therefore let the science park boundaries overlap with neighborhood boundaries when boundaries are arbitrarily close or when no firms are located in the neighborhood remained. We then calculate the share of land of each neighborhood that is in a science park in the year before the year of observation. To calculate the distance to the science park boundary for each neighborhood, we calculate for each point (using a $5 \mathrm{~m}$ by $5 \mathrm{~m}$ grid) within the neighborhood the distance to the nearest science park boundary. Then, we take the average of the distances within the neighborhood (where negative distances are locations outside of the science parks). Figure 3 plots the relationship between the average distance to the nearest science park boundary in a neighborhood and the share of the neighborhood that is part of a science park for 2007. Because we do not know the exact location of firms and we use microdata, this may imply a measurement error, which potentially leads to a downward bias of the estimated effect of science parks in a linear model. To avoid the problem of measurement error, we exclude observations in neighborhoods that have shares that deviate from zero or one (approximately $1 \%$ of the neighborhoods, indicated by the grey dots in Figure 3). We also use another (cross-sectional) data set in the robustness analysis for which we have the exact location of firms (see Online Appendix C.4).

In Table 1, we present descriptive statistics of the variables used in our analysis. The table shows that the average output is much higher for firms in science parks. However, this difference may be caused by some very large firms (such as Foxconn, a large high-tech multinational). The number of workers is indeed somewhat higher in science parks, but the amount of physical capital is not. Firm age and the number of start-ups are on average similar across science parks and other areas.

In Figure 4, we plot the average logarithm of firm output per worker and the logarithm of the value added per worker over the years for science parks and other areas. Productivity in science parks is approximately $30 \%$ higher compared with productivity in other areas (Figure 4). This figure suggests that firms in science parks are more productive, or that science parks attract productive firms. In Figure 5, we plot value added over time. The difference between science parks and other areas is approximately $25 \%$. Note that we do not have data on value added for the year 2004. In Online Appendix B.1, we also display a similar figure in which we compare output and value added before science parks were opened to test whether pretrends are similar. We find evidence that this is indeed more or less the case. ${ }^{7}$

For approximately $20 \%$ of the firms, we observe a change in firm location. Only $20 \%$ of the moving firms originating from a regular area relocate into a science park. For about $75 \%$ of the relocations, the science park status does not change (so either stay inside or outside science parks). The remaining firms move from a science park into a regular area. The average moving distance is $8.5 \mathrm{~km}$ and the median moving distance is $4.3 \mathrm{~km}$. Both of these observations suggest that the science park policy does not just attract firms from across the boundary. We

${ }^{7}$ However, for our identification strategy, the assumption of identical trends is not required. Our preferred specifications include firm fixed effects that control for any pretreatment differences in productivity or value added between firms in science parks and outside those areas. 
TABLE 1 Descriptive statistics of National Statistics Bureau sample

\begin{tabular}{|c|c|c|c|c|c|c|c|c|}
\hline & \multicolumn{4}{|c|}{ Other areas } & \multicolumn{4}{|c|}{ Science parks } \\
\hline & $\mu$ & $\sigma$ & Min & Max & $\mu$ & $\sigma$ & Min & Max \\
\hline Output (in $10,000,000 ¥$ ) & 137.777 & $1,178.534$ & 0.037 & $75,736.800$ & 297.104 & $2,254.364$ & 0.163 & $75,736.800$ \\
\hline $\begin{array}{l}\text { Value added (in } \\
10,000,000 ¥ \text { ) }\end{array}$ & 38.616 & 485.911 & 0.006 & $40,943.920$ & 82.326 & 683.120 & 0.001 & $25,974.810$ \\
\hline $\begin{array}{l}\text { Wage per worker (in } \\
10,000 ¥ \text { ) }\end{array}$ & 21.599 & 22.407 & 7.500 & 750.000 & 26.964 & 26.549 & 7.516 & 437.834 \\
\hline $\begin{array}{l}\text { Science park (in \% of the } \\
\text { neighborhood) }\end{array}$ & 0.027 & 0.097 & 0.000 & 0.775 & 0.768 & 0.302 & 0.039 & 1.000 \\
\hline $\begin{array}{l}\text { Distance to science park } \\
\text { boundary (in } \mathrm{km} \text { ) }\end{array}$ & -3.954 & 3.152 & -14.049 & 1.471 & 0.213 & 0.545 & -2.321 & 1.471 \\
\hline Special economic zone & 0.311 & & & & 0.350 & & & \\
\hline $\begin{array}{l}\text { Distance to employment } \\
\text { center (in } \mathrm{km} \text { ) }\end{array}$ & 15.551 & 9.899 & 0.350 & 48.032 & 15.327 & 9.580 & 2.318 & 38.888 \\
\hline $\begin{array}{l}\text { Distance to highway } \\
\text { ramp (in } \mathrm{km} \text { ) }\end{array}$ & 4.249 & 3.282 & 0.261 & 31.102 & 4.063 & 2.853 & 0.573 & 26.360 \\
\hline $\begin{array}{l}\text { Distance to } \\
\text { airport (in km) }\end{array}$ & 23.369 & 14.011 & 0.849 & 77.648 & 20.638 & 12.992 & 4.796 & 70.108 \\
\hline $\begin{array}{l}\text { Distance to } \\
\text { seaport (in km) }\end{array}$ & 19.779 & 8.963 & 0.700 & 39.886 & 20.031 & 8.508 & 8.491 & 33.761 \\
\hline Restricted zone & 0.262 & & & & 0.189 & & & \\
\hline Employees & 397.451 & $1,120.086$ & 2.000 & $82,067.010$ & 567.525 & $2,480.965$ & 2.000 & $82,067.010$ \\
\hline Capital (in $10,000 ¥$ ) & 3.397 & 43.919 & 0.000 & $2,525.370$ & 3.846 & 17.762 & 0.000 & 751.068 \\
\hline Start-up & 0.010 & & & & 0.013 & & & \\
\hline Age $0-5$ & 0.425 & & & & 0.445 & & & \\
\hline Age $6-10$ & 0.319 & & & & 0.312 & & & \\
\hline Age $>10$ & 0.256 & & & & 0.243 & & & \\
\hline Privately owned firm & 0.334 & & & & 0.393 & & & \\
\hline HTM-owned firm & 0.511 & & & & 0.424 & & & \\
\hline Foreign-owned firm & 0.155 & & & & 0.183 & & & \\
\hline Tax rate & 0.017 & 0.080 & -1.000 & 1.000 & 0.019 & 0.084 & -1.000 & 1.000 \\
\hline
\end{tabular}

Notes. The effective number of observations for firms outside of science parks is 20,739 and for firms inside science parks is 4,279. For value added and wages we have 15,229 and 19,210 observations outside science parks, respectively, and 3,310 and 4,048 observations inside science parks, respectively. We exclude state-owned firms.

also plot a histogram of moving distances in Online Appendix B. 2 showing that only $10 \%$ of the mover occurs within $1 \mathrm{~km}$. However, note that in our preferred specifications, we identify the effect based on firms that do not move.

\section{4 | ECONOMETRIC FRAMEWORK}

\section{1 | Set-up}

We assume that productivity $q_{j z t}$ of firm $j$ located in neighborhood $z$ in year $t$ can be described by a Cobb-Douglas production function (Greenstone, Hornbeck, \& Moretti, 2010; Moretti, 2004): 


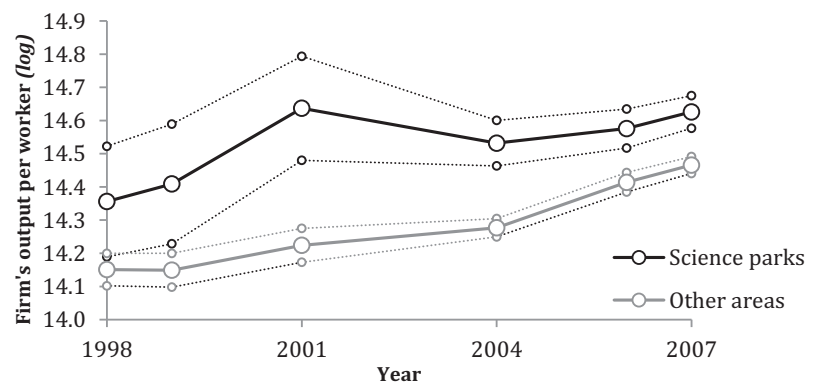

FIGURE 4 Output and value added in science parks and other areas, log of firms output per worker

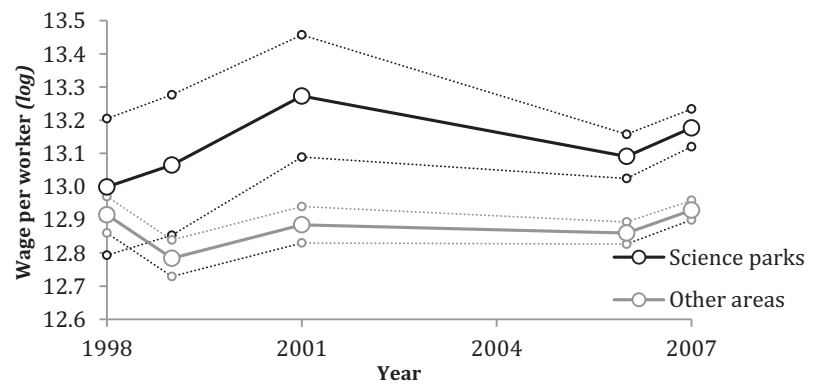

FIGURE 5 Output and value added in science parks and other areas, log of firms value added per worker

$$
q_{j z t}=A_{z t} \prod_{M=1}^{M} x_{j t m}^{\alpha_{m}} \nu_{i j t}
$$

where $x_{j t m}$ is an input $m$, such as labor and capital, $m=1, \ldots, M, \alpha_{m}$ is a productivity parameter, $A_{z t}$ denotes the location-specific technology level, and $v_{j z t}$ captures unobserved heterogeneity. It is assumed that $\log \nu_{j z t}=\eta_{j s t}+\phi_{t}+\epsilon_{j z t}$, where $\eta_{j s t}$ denotes industrial sector $s$ fixed effects (which may sometimes change over time for a firm), $\phi_{t}$ are time fixed effects and $\epsilon_{j z t}$ is an independently and identically distributed error term. We assume that technology $A_{z t}$ only depends on the share of a neighborhood in a science park $p_{z t}$ (e.g., because of institutional arrangements and technology spillovers between firms located there), so $A_{z t}=\mathrm{e}^{\beta p_{z t}}$. We note that $p_{z t}$ is positive for firms in a science park in the year after the opening of the science park, which seems reasonable because we do not know the exact opening date of the science park. Equation (6) is unlikely to identify a causal effect of science parks (a) if the locations of science parks are not randomly distributed over space and (b) if more productive firms sort themselves in science parks.

Most likely, the locations of science parks are not randomly chosen. For example, the selection of a location may be based on the existing spatial distribution of high-tech industries. We address this issue by using spatial differencing. We compare science parks to neighboring areas that are untreated but that are otherwise similar (Bayer, Ferreira, \& McMillan, 2007; Black, 1999). Hence, we estimate a weighted regression, where the weight is given by:

$$
w_{z \bar{t}}=\left(1-\frac{d_{z \bar{t}}}{d_{T}}\right) 1_{d_{z \bar{t}}<d_{T}},
$$


which implies that the weight is zero when a location is further than the threshold distance $d_{T} \mathrm{~km}$ from a science park boundary in $\bar{t}=2007$. We include a set of boundary "fixed effects" $\theta_{z b \bar{t}}$, which are calculated as the share of a neighborhood that is closest to boundary $b$ in $\bar{t}$ and zero otherwise. ${ }^{8}$ We also control for observable neighborhood variables denoted by $n_{z t}$. In Online Appendix C.8, we test for robustness of the results with respect to the choice of $d_{T}$ and experiment with flexible spatial trends that may pick up unobserved factors. Note that spatial differencing implies that $\beta$ will be an underestimate of the causal effect when the benefits of science park policies extend beyond the science park boundaries (e.g., via fast internet). However, we have argued that most policies exclusively apply to firms inside science parks, so we do not consider this as a major problem.

However, so far we do not control for the fact that firms may be more productive for unobserved reasons and sort themselves in science parks. It may even be that less productive firms are banned from science parks, while they are allowed to locate elsewhere. We therefore include firm fixed effects, which leads to the preferred specification

$$
\log q_{j z t}=\alpha \log x_{j t}+\beta p_{z t}+\zeta n_{z t}+\theta_{z b \bar{t}}+\phi_{t}+\eta_{j s t}+\omega_{j}+\epsilon_{j z t}
$$

where $\omega_{j}$ denotes a firm fixed effect. Hence, we assume that unobserved firm effects are log-separable from other effects. By including firm fixed effects, we exploit temporal variation in the assignment of science parks: we compare firms' productivity before and after the opening of a science park vis-à-vis the productivity of a firm located close to a science park. A second source of identifying variation is derived from firms that relocate. The above equation identifies a causal effect if unobserved firm productivity trends are uncorrelated with science parks. ${ }^{9}$

However, one could argue that firms relocate to science parks in certain stages of their productivity development. Furthermore, we might not properly control for any time-invariant location attributes that are correlated with the assignment of science parks. To rule out that unobserved time-invariant locational attributes explain productivity the estimated science park effect, we also estimate a specification in which we include firm-neighborhood fixed effects $\omega_{j z}$. Hence, we control for all time-invariant characteristics of a location and a firm. Because we identify the effect on staying firms, it is unlikely that the comparison of nearby companies along the science park boundary is confounded by selection of companies due to shocks to expectations on innovative capacity and productivity. We will investigate this in more detail in Online Appendix C.7. Another worry one might have is that $\beta$ will be an overestimate if firms just move across the boundary, as is often documented in the previous literature (see, e.g., Einiö \& Overman, 2012). We argue that firm-neighborhood fixed effects should exclude such moves as an interpretation of our result, because we do not identify the effect on moving firms, but exclusively on firms that stay. Nevertheless, to fully rule out the possibility that using local spatial differencing leads to an overestimate, we pursue an alternative identification strategy in Online Appendix C.1 in which the "control" locations are not (necessarily) close to treatment areas.

\section{5 | REGRESSION RESULTS}

\section{1 | Productivity effects}

Table 2 reports the estimates based on Equations (6-8). We start with a simple regression based on Equation (6), in which we regress the logarithm of output on whether a neighborhood is part of a science park while controlling for

\footnotetext{
${ }^{8}$ Note that if we knew the exact location of firms rather than at the neighbourhood level, it would lead to the inclusion of dummies that equal one when the observation is closest to boundary $b$.

${ }^{9}$ Note that Equation (8) implies that the effect of science parks is immediate and permanent, so that no anticipation or adjustment effects exists. We test this assumption in more detail in Online Appendix C.10.
} 
TABLE 2 Baseline regression results on the impact of science parks on productivity (Dependent variable: the logarithm of firms' yearly output)

\begin{tabular}{|c|c|c|c|c|c|c|c|}
\hline & $\begin{array}{l}\text { (1) } \\
\text { OLS }\end{array}$ & $\begin{array}{l}\text { (2) } \\
\text { OLS }\end{array}$ & $\begin{array}{l}\text { (3) } \\
\text { WLS }\end{array}$ & $\begin{array}{l}\text { (4) } \\
\text { WLS }\end{array}$ & $\begin{array}{l}\text { (5) } \\
\text { WLS }\end{array}$ & $\begin{array}{l}\text { (6) } \\
\text { WLS }\end{array}$ & $\begin{array}{l}\text { (7) } \\
\text { WLS }\end{array}$ \\
\hline \multirow[t]{2}{*}{ Science park } & $0.230^{*}$ & 0.174 & $0.219^{* * *}$ & $0.231^{* * *}$ & $0.239^{* *}$ & $0.195^{* *}$ & $0.165^{*}$ \\
\hline & $(0.124)$ & (0.107) & $(0.0778)$ & $(0.0725)$ & $(0.100)$ & $(0.0881)$ & $(0.0954)$ \\
\hline \multirow[t]{2}{*}{ Employees (log) } & $0.546^{* * *}$ & $0.614^{* * *}$ & $0.631^{* * *}$ & $0.635^{* * *}$ & $0.588^{* * *}$ & $0.587^{* * *}$ & $0.582^{* * *}$ \\
\hline & $(0.0164)$ & $(0.0152)$ & $(0.0282)$ & $(0.0288)$ & $(0.0443)$ & $(0.0438)$ & $(0.0432)$ \\
\hline \multirow[t]{2}{*}{ Capital (log) } & $0.267^{* * *}$ & $0.225^{* * *}$ & $0.249^{* * *}$ & $0.247^{* * *}$ & $0.0949^{* * *}$ & $0.0926^{* * *}$ & $0.0886^{* *}$ \\
\hline & $(0.0113)$ & $(0.00897)$ & $(0.0158)$ & $(0.0158)$ & $(0.0329)$ & $(0.0327)$ & $(0.0351)$ \\
\hline \multirow[t]{2}{*}{ Start-up } & & $-0.281^{* * *}$ & -0.167 & -0.160 & $-0.471^{* * *}$ & $-0.478^{* * *}$ & $-0.466^{* * *}$ \\
\hline & & $(0.0689)$ & $(0.114)$ & $(0.112)$ & $(0.149)$ & $(0.150)$ & $(0.156)$ \\
\hline \multirow[t]{2}{*}{ Age 0-5 } & & -0.0167 & $0.101^{*}$ & $0.105^{*}$ & 0.0522 & 0.0521 & 0.0460 \\
\hline & & $(0.0295)$ & $(0.0540)$ & $(0.0540)$ & $(0.0720)$ & (0.0719) & $(0.0757)$ \\
\hline \multirow[t]{2}{*}{ Age 6-10 } & & 0.0290 & $0.136^{* * *}$ & $0.133^{* * *}$ & 0.0737 & 0.0770 & 0.0799 \\
\hline & & $(0.0254)$ & $(0.0408)$ & (0.0409) & $(0.0556)$ & (0.0558) & $(0.0583)$ \\
\hline \multirow[t]{2}{*}{ HTM-owned firm } & & $-0.128^{* * *}$ & $-0.0689^{* *}$ & $-0.0651^{* *}$ & $0.190^{*}$ & $0.194^{*}$ & 0.208 \\
\hline & & $(0.0279)$ & $(0.0335)$ & $(0.0328)$ & $(0.110)$ & $(0.111)$ & $(0.127)$ \\
\hline \multirow[t]{2}{*}{ Foreign-owned firm } & & $0.172^{* * *}$ & $0.199^{* * *}$ & $0.204^{* * *}$ & 0.155 & 0.157 & 0.186 \\
\hline & & $(0.0372)$ & $(0.0624)$ & $(0.0624)$ & $(0.101)$ & $(0.101)$ & $(0.113)$ \\
\hline \multirow[t]{2}{*}{ Special economic zone (SEZ) } & & & & $0.180^{* *}$ & 0.195 & $0.940^{* *}$ & \\
\hline & & & & $(0.0861)$ & $(0.347)$ & $(0.473)$ & \\
\hline \multirow[t]{2}{*}{ Distance to employment center (log) } & & & & $-0.321^{* *}$ & 0.0548 & $0.412^{* *}$ & \\
\hline & & & & $(0.144)$ & $(0.149)$ & $(0.189)$ & \\
\hline \multirow[t]{2}{*}{ Distance to highway ramp (log) } & & & & $-0.115^{* * *}$ & -0.0813 & -0.126 & \\
\hline & & & & $(0.0391)$ & $(0.149)$ & $(0.176)$ & \\
\hline \multirow[t]{2}{*}{ Distance to airport (log) } & & & & -0.0128 & 0.234 & 1.965 & \\
\hline & & & & $(0.150)$ & $(0.308)$ & (1.709) & \\
\hline \multirow[t]{2}{*}{ Distance to seaport (log) } & & & & $0.507^{*}$ & -0.214 & -1.217 & \\
\hline & & & & $(0.290)$ & $(0.538)$ & $(5.752)$ & \\
\hline \multirow[t]{2}{*}{ Restricted zone } & & & & 0.0442 & 0.172 & -0.00818 & \\
\hline & & & & $(0.0820)$ & $(0.240)$ & $(0.265)$ & \\
\hline Geographic coordinates $\mathrm{Y}(\cdot)$ & No & No & No & No & No & Yes & No \\
\hline Year FE (6) & Yes & Yes & Yes & Yes & Yes & Yes & Yes \\
\hline Industry FE (33) & No & Yes & Yes & Yes & Yes & Yes & Yes \\
\hline Firm FE $(3,707)$ & No & No & No & No & Yes & Yes & Yes \\
\hline Firm-neighborhood FE $(3,910)$ & No & No & No & No & No & No & Yes \\
\hline Science park boundary FE (15) & No & No & Yes & Yes & Yes & Yes & Yes \\
\hline Number of observations & 19,215 & 19,215 & 8,311 & 8,311 & 8,311 & 8,311 & 8,311 \\
\hline$R^{2}$ & 0.549 & 0.597 & 0.641 & 0.643 & 0.942 & 0.943 & 0.947 \\
\hline
\end{tabular}

Notes: The weights for the weighted least squares (WLS) specifications are given by $\omega_{z \bar{t}}=\left(1-d_{z \bar{t}} / d_{T}\right) 1_{d_{z \bar{t}}<d_{T}}$, where $d_{T}=2.5$. In column (6), we include a flexible function $\mathrm{Y}(\cdot)$ of geographic coordinates, which is approximated by a fifth-order polynomial function of geographic coordinates, including interactions. Standard errors are clustered at the neighborhood level and in parentheses.

*** Significant at the 0.01 level.

** Significant at the 0.05 level.

*Significant at the 0.10 level. 
workforce size, the capital stock and year fixed effects. ${ }^{10}$ The coefficient suggests that firms are $26 \%$ more productive in science parks. ${ }^{11}$ This effect should not be interpreted as a causal effect of science park policies because the allocation of science parks may be nonrandom. In column (2), we include additional firm control variables and industrial sector fixed effects. The coefficient is somewhat lower and statistically insignificant.

If the location of science parks is not random and depends on geographic location and industrial conditions, this estimate is likely to be biased. For example, it might be that science parks are established at locations that have favorable geographical features, such as access to highways. We therefore use spatial differencing. This approach should address the problem of spatial unobservables, as we focus on areas close to science park boundaries, which should have a similar geography. On such a small spatial scale, the boundary of science parks is considered to be random. We then only include observations that are within $2.5 \mathrm{kms}$ of a science park boundary and include science park boundary fixed effects. In column (3), it can be observed that firms are $24 \%$ more productive in science parks.

The effect is almost identical if we include a range of neighborhood control variables, such as distance to the nearest employment center, distance to international airports and seaports, and distance to the nearest highway ramp (column (4)). Because the coefficient hardly changes, this suggests that boundary fixed effects capture important locational endowments well.

In column (5) of Table 2 we include firm fixed effects to control for sorting. Because of entry requirements, lowproductivity firms may not be allowed to locate in science parks, thus mechanically raising average productivity inside the science park. However, by investigating the productivity of the same firm before and after the opening of a science park, we control for these entry requirements. The coefficient is now somewhat higher: Science park policies seem to have increased firms' productivity by $27 \%$, which is very similar to the previous specifications. Possibly, neighborhood variables might not capture all of the spatial variables that are correlated with the boundaries of science parks. In column (6), we therefore add a flexible fifth-order polynomial function of geographic coordinates. The results indicate that the effect is slightly lower compared with the previous specification, but it still is statistically significant at the $5 \%$ level. An alternative approach is to include firm-neighborhood fixed effects to control for all time-invariant location attributes, so that we only use variation of firms that do not relocate. Column (7) indicates that firms that do not relocate have seen an increase in productivity of $18 \%$ after the opening of a science park.

The results undoubtedly suggest a strong and meaningful productivity effect of science parks, even if we control for firm selection. Our effects are in the same order of magnitude as those of Wang (2013). ${ }^{12}$

\section{2 | Wages}

Do the productivity improvements in science parks translate into higher wages? If, for instance, workers are very mobile and labor supply is elastic, the wage impact of science parks should be minor. Conversely, when workers have strong idiosyncratic preferences and labor is elastic, we expect larger wage growth due to the opening of science parks. We therefore also run regressions in which the wage is the dependent variable. The wage is defined as the average wage per worker in a firm (defined as the total wage bill divided by the number of employees). This

\footnotetext{
${ }^{10}$ To estimate the standard errors of the parameters of interest, one may cluster standard errors over space (at the science park area or neighbourhood level) or over time (at the firm level). Our pragmatic approach is that we cluster at the neighbourhood level because it leads to the largest standard errors and therefore to the most conservative conclusions. Nevertheless, it appears that the standard errors are very similar no matter whether we cluster at the science park, neighbourhood or firm level. We may also estimate a system of equations using seemingly unrelated regressions, including the regression equations for employment and capital. This approach would be more efficient and would therefore lead to lower standard errors. The results are available upon request.

${ }^{11}$ The marginal effect is calculated as $\mathrm{e}^{\hat{\beta}}-1$.

${ }^{12}$ The control variables have plausible signs. Production inputs, such as employment and capital, increase production. Start-ups have a lower production (15-61\%). Conditional on being a start-up, younger firms seem to be somewhat more productive. Furthermore, we find some evidence that foreign-owned firms have a higher output (17-23\%). The effect of distance to employment centres is unclear: when we include firm fixed effects, the sign switches. However, we note that if we would exclude the distance to the nearest employment centre, the effect of science parks is hardly affected.
} 
TABLE 3 Regression results of the impact of science parks on firm wages (Dependent variable: the logarithm of the average wage)

\begin{tabular}{|llllllll} 
& $(1)$ & $(2)$ & $(3)$ & $(4)$ & $(5)$ & $(6)$ & $(7)$ \\
& OLS & OLS & WLS & WLS & WLS & WLS & WLS \\
\hline Science park & $0.202^{* *}$ & $0.187^{* *}$ & $0.159^{* * *}$ & $0.147^{* * *}$ & $0.112^{* *}$ & $0.128^{* * *}$ & $0.112^{* * *}$ \\
\hline Firm variables (5) & $(0.0878)$ & $(0.0737)$ & $(0.0486)$ & $(0.0408)$ & $(0.0479)$ & $(0.0433)$ & $(0.0427)$ \\
\hline Neighborhood variables (6) & No & Yes & Yes & Yes & Yes & Yes & Yes \\
\hline Geographic coordinates Y(•) & No & No & No & Yes & Yes & Yes & Yes \\
\hline Year FE (6) & Nes & Yes & Yes & No & No & Yes & No \\
\hline Industry FE (33) & No & Yes & Yes & Yes & Yes & Yes & Yes \\
\hline Firm FE (3,582) & No & No & No & No & Yes & Yes & Yes \\
\hline Firm-neighborhood FE (3,773) & No & No & No & No & No & No & Yes \\
\hline Science park boundary FE (15) & No & No & Yes & Yes & Yes & Yes & Yes \\
\hline Number of observations & 17,814 & 17,814 & 7,697 & 7,697 & 7,697 & 7,697 & 7,697 \\
\hline$R^{2}$ & 0.182 & 0.242 & 0.334 & 0.343 & 0.778 & 0.780 & 0.790 \\
\hline
\end{tabular}

Notes: The weights for the weighted least squares (WLS) specifications are given by $\omega_{z \bar{t}}=\left(1-d_{z \bar{t}} / d_{T}\right) 1_{d_{z \bar{t}}<d_{T}}$, where $d_{T}=2.5$. In column (6), we include a flexible function $\mathrm{Y}(\bullet)$ of geographic coordinates, which is approximated by a fifth-order polynomial function of geographic coordinates, including interactions. Standard errors are clustered at the neighborhood level and in parentheses.

${ }^{* * *}$ Significant at the 0.01 level.

${ }^{* *}$ Significant at the 0.05 level.

*Significant at the 0.10 level

measure may be slightly noisy if there are outliers (e.g., CEOs who earn a lot compared with the average worker). It is also not available for all firms (approximately $7.5 \%$ of the observations are missing). Table 3 reports the regression results.

Again, we start with the naive specification in Table 3, column (1). The coefficient suggests that wages are $22 \%$ higher in science parks. This effect is slightly smaller once we include firm control variables and industry fixed effects (column (2)). In column (3), we use spatial differencing to improve on the identification of a causal effect of science park policies on wages. Again, we find a positive and meaningful effect of science parks on wages (17\%). This coefficient is very similar when we include neighborhood variables in column (4). Once we control for firm sorting by including firm fixed effects in column (5), the effect of science park policies on wages is $11.9 \%$. This effect becomes statistically stronger when we include a flexible function of geographic coordinates (column (6)) or when we only focus on firms that have not relocated by including firm-neighborhood fixed effects (column (7)). Hence, the results unambiguously suggest that wages have risen due to science park policies, potentially pointing to benefits for local workers. The wage grows at a somewhat smaller rate than productivity, suggesting that workers do not appropriate all productivity increases, or that there are workers changing jobs.

\section{3 | Displacement effects and deadweight losses}

Our previous results suggest substantial productivity effects of the Shenzhen science parks, but they may be accompanied with displacement of capital and labor. Our theoretical model implies that if labor or capital moves in response to science park policies, the policies may cause deadweight losses by inefficiently relocating factors. 
TABLE 4 Regression results of the impact of science parks on workforce size and the capital stock (Dependent variable: the logarithm of firms' employment)

\begin{tabular}{|c|c|c|c|c|c|c|c|}
\hline & $\begin{array}{l}\text { (1) } \\
\text { OLS }\end{array}$ & $\begin{array}{l}\text { (2) } \\
\text { OLS }\end{array}$ & $\begin{array}{l}\text { (3) } \\
\text { WLS }\end{array}$ & $\begin{array}{l}\text { (4) } \\
\text { WLS }\end{array}$ & $\begin{array}{l}\text { (5) } \\
\text { WLS }\end{array}$ & $\begin{array}{l}\text { (6) } \\
\text { WLS }\end{array}$ & $\begin{array}{l}\text { (7) } \\
\text { WLS }\end{array}$ \\
\hline \multicolumn{8}{|l|}{ Panel A: Workforce size } \\
\hline \multirow[t]{2}{*}{ Science park } & -0.0579 & -0.0313 & 0.0507 & 0.0728 & $0.149^{* *}$ & 0.131 & 0.110 \\
\hline & $(0.0886)$ & (0.0933) & $(0.0585)$ & $(0.0593)$ & $(0.0745)$ & $(0.0822)$ & (0.0889) \\
\hline Firm variables (5) & No & Yes & Yes & Yes & Yes & Yes & Yes \\
\hline Neighborhood variables (6) & No & No & No & Yes & Yes & Yes & Yes \\
\hline Geographic coordinates $\mathrm{Y}(\bullet)$ & No & No & No & No & No & Yes & No \\
\hline Year FE (6) & Yes & Yes & Yes & Yes & Yes & Yes & Yes \\
\hline Industry FE (33) & No & Yes & Yes & Yes & Yes & Yes & Yes \\
\hline Firm FE $(3,707)$ & No & No & No & No & Yes & Yes & Yes \\
\hline Firm-neighborhood FE $(3,910)$ & No & No & No & No & No & No & Yes \\
\hline Science park boundary FE (15) & No & No & Yes & Yes & Yes & Yes & Yes \\
\hline Number of observations & 19,215 & 19,215 & 8,311 & 8,311 & 8,311 & 8,311 & 8,311 \\
\hline$R^{2}$ & 0.012 & 0.165 & 0.206 & 0.212 & 0.936 & 0.936 & 0.941 \\
\hline \multicolumn{8}{|l|}{ Panel B: Capital stock } \\
\hline \multirow[t]{2}{*}{ Science park } & $0.465^{* * *}$ & $0.401^{* * *}$ & $0.467^{* * *}$ & $0.485^{* * *}$ & 0.0121 & -0.0305 & -0.0538 \\
\hline & $(0.155)$ & $(0.116)$ & $(0.144)$ & $(0.142)$ & $(0.109)$ & $(0.107)$ & $(0.0926)$ \\
\hline Firm variables (5) & No & Yes & Yes & Yes & Yes & Yes & Yes \\
\hline Neighborhood variables (6) & No & No & No & Yes & Yes & Yes & Yes \\
\hline Geographic co-ordinates $\mathrm{Y}(\cdot)$ & No & No & No & No & No & Yes & No \\
\hline Year FE (6) & Yes & Yes & Yes & Yes & Yes & Yes & Yes \\
\hline Industry FE (33) & No & Yes & Yes & Yes & Yes & Yes & Yes \\
\hline Firm FE $(3,707)$ & No & No & No & No & Yes & Yes & Yes \\
\hline Firm-neighborhood FE $(3,910)$ & No & No & No & No & No & No & Yes \\
\hline Science park boundary FE (15) & No & No & Yes & Yes & Yes & Yes & Yes \\
\hline Number of observations & 19,215 & 19,215 & 8,311 & 8,311 & 8,311 & 8,311 & 8,311 \\
\hline$R^{2}$ & 0.053 & 0.202 & 0.235 & 0.239 & 0.911 & 0.911 & 0.918 \\
\hline
\end{tabular}

Notes: The weights for the weighted least squares (WLS) specifications are given by $\omega_{z \bar{z}}=\left(1-d_{\bar{z} \bar{t}} / d_{T}\right) 1_{d_{z \bar{t}}<d \tau}$, where $d_{T}=2.5$. In column (6), we include a flexible function $\mathrm{Y}(\cdot)$ of geographic co-ordinates, which is approximated by a fifth-order polynomial function of geographic coordinates, including interactions. Standard errors are clustered at the neighborhood level and in parentheses.

${ }^{* * *}$ Significant at the 0.01 level.

${ }^{* *}$ Significant at the 0.05 level.

${ }^{*}$ Significant at the 0.10 level.

Table 4 shows the impacts of the science park policies on workforce size and capital employment. Panel A reports regressions with workforce size as a dependent variable. The naive specification in column (1) suggests that firms in science parks do not have a larger workforce than firms outside of those areas. This result also holds if we include firm control variables and industry fixed effects (column (2)), if we use spatial differencing (column (3)), and if we include neighborhood variables (column (4)). However, when we control for firm sorting by including firm fixed effects in column (5), the results show that the coefficient becomes positive and statistically significant. The 


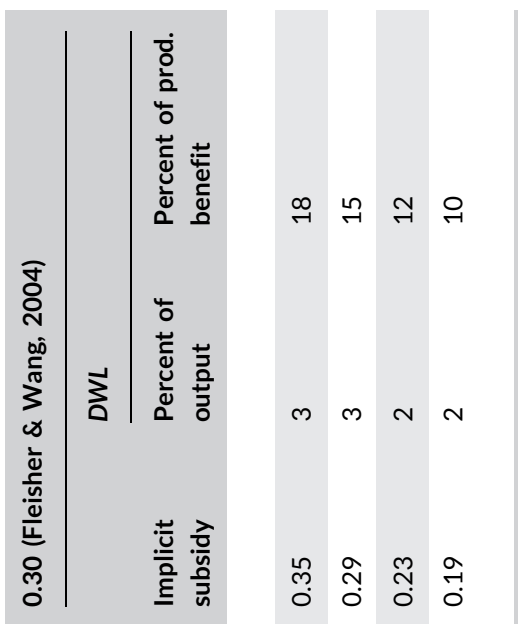

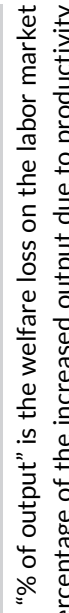

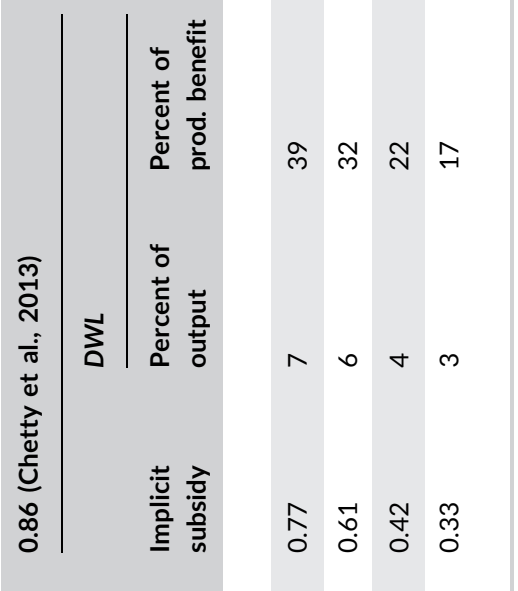

ن

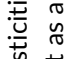

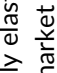

층 ํํำ

要

要

흥

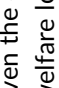

on

焉

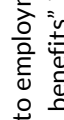

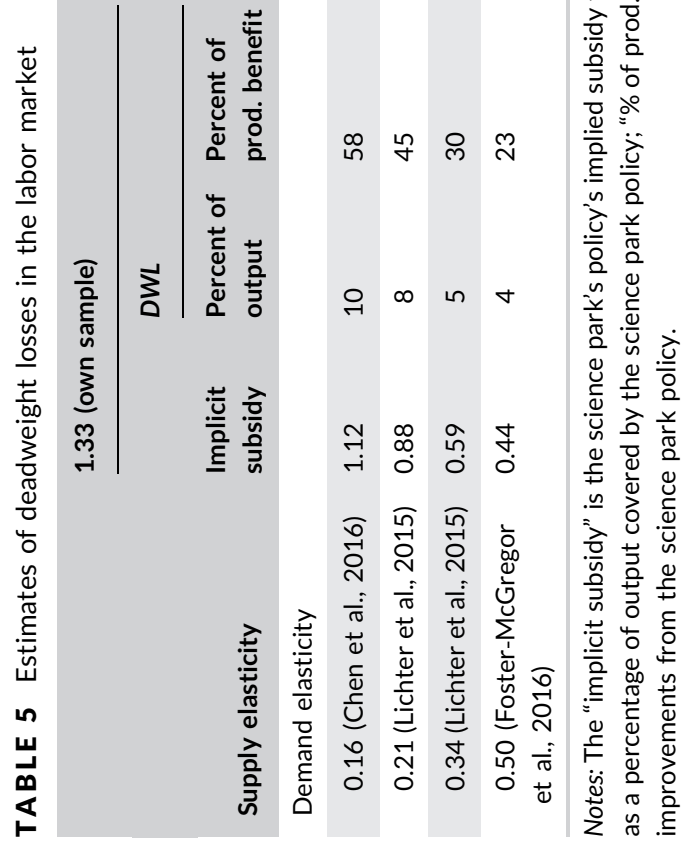


coefficient suggests that firms employ $16 \%$ more workers due to science park policies. When we include a flexible function of geographic coordinates in column (6), the point estimate is similar but not statistically significant at conventional levels. This result also holds if we include firm-neighborhood fixed effects in column (7). Hence, although the estimates are imprecise, the policies seem to have led to mobility responses of workers. In Panel B of Table 4, we investigate whether the increase in workforce size is accompanied by increases in the capital stock. This inquiry is interesting, as displacement effects may refer to both changes in the labor force and in the capital stock (see Equation (4)). Column (1) provides the naive regressions without any locational or firm controls. The coefficient suggests that firms operating in science parks use more capital. This result also holds if we include firm control variables and if we focus on observations close to the science park boundaries, and include science park fixed effects. However, this effect is unlikely to be a causal effect of science park policies because high-tech firms that have relatively high shares of capital use are more likely to end up in science parks because of entry requirements. Indeed, once we include firm fixed effects, the coefficient becomes statistically insignificant and essentially equal to zero (columns (5)-(7)).

Our theoretical model offers a framework to evaluate the displacement effects of Shenzhen's science park policies. From Equation (5), we can write the welfare effects of the science park policy $p_{z}$ as

$$
\begin{aligned}
\Delta \hat{\mathcal{R} W} & =e_{A} \frac{\mathrm{d} A_{z t} / \mathrm{d} p_{z t}}{A_{z t}}-\alpha_{\ell} e_{\ell} \frac{\mathrm{d} t_{1}}{\mathrm{~d} p_{z}}-\alpha_{k} e_{k} \frac{\mathrm{d} s_{1}}{\mathrm{~d} p_{z}} \\
& =\left(\mathrm{e}^{\hat{\beta}_{A}}-1\right)-\hat{\alpha}_{\ell} \frac{\mathrm{d} t_{1}}{\mathrm{~d} p_{z}}\left(\mathrm{e}^{\hat{\beta}_{\ell}}-1\right)-\hat{\alpha}_{k} \frac{\mathrm{d} s_{1}}{\mathrm{~d} p_{z}}\left(\mathrm{e}^{\hat{\beta}_{k}}-1\right),
\end{aligned}
$$

where the circumflexes refer to estimated values. The welfare effect comprises three terms: the direct productivity increase $\left(\mathrm{e}^{\hat{\beta}_{A}}-1\right)$; and the two deadweight losses on the markets for labor and capital. The magnitude of the individual components can be compared here, because they are all scaled to relative change to output value. All these values can be estimated from our data, except $d t_{1} / d p_{z}$ and $d s_{1} / d p_{z}$, which represent factor price changes due to the science park policies, like subsidies. While we observe that the policies imply relocations of workers, the Chinese government does not publish what exact instruments are used, or what their costs are.

To approximate the subsidies and labor-related policies in our welfare function, $\mathrm{dt} t_{1} / \mathrm{d} p_{z}$, we use an indirect approach. The science park policy pushes up the equilibrium price of labor by around $12 \%$ (see Table 3, column (5)). However, the subsidy may be larger than that, if the pass-through is imperfect. To understand whether the observed wage change is much smaller than the (implicit) labor-related subsidies that firms receive, we need to know the elasticity of labor supply and labor demand. Assuming constant elasticity of labor supply and demand, we can reconstruct the implicit labor-related subsidy that a firm receives for the wage to rise $12 \%$ as: $\left(s_{1} / \varepsilon_{S}\right) /\left(1 / \varepsilon_{S}+1 /\left|\varepsilon_{D}\right|\right)=0.12$. As capital appears unresponsive in the preferred specifications (see Panel B, Table 4), the deadweight losses in the capital market are small by construction, and we assume they are more or less equal to zero.

We can infer an elasticity of labor supply from our analysis, because we have employment and wage data. We assume that our identification strategy isolates an exogenous labor demand shock. The science park policy targets firms and potentially firm employment, and arguably has no direct amenity benefits to consumers. Workers benefit from the policy conditional on employment in a firm in a science park. Using this, our estimated wage and employment elasticities change along a constant labor supply curve. Our preferred estimates suggest that a $12 \%$ wage increase is associated with a 16\% employment increase (Table 4, column 5 with firm-level fixed effects), implying a labor supply elasticity of around 1.33. We supplement this estimate with labor supply elasticities from the literature, as our elasticity of labor supply is high relative to other estimates in the literature. For comparison, we add a benchmark elasticity of 0.86 for the United States economy (Chetty, Guren, Manoli, \& Weber, 2013). We also add an estimate of 0.3 from rural China (Fleisher \& Wang, 2004). As this sample represents rural workers under poorer conditions, while our sample represents more skilled workers used at high-tech firms, we consider 0.3 as a lower bound estimate of the labor supply elasticity. 
The estimated labor demand elasticities vary throughout the literature. Chen, $\mathrm{Li}$, and Yin (2016) find elasticities around 0.16 for exporting, capital intensive Chinese firms. Such firms may be representative for our sample, although the estimates seem to be on the lower end. Surveying international results, Lichter, Peichl, and Siegloch (2015) report average demand elasticities of 0.21 (short-run) to 0.34 (medium-run). On the higher end, FosterMcGregor, Poeschl, and Stehrer (2016) find labor demand elasticities for skilled workers in developing countries of 0.44 .

Table 5 reports our calculations for the deadweight losses due to worker displacement. With high labor demand elasticities and low supply elasticities, the implied implicit subsidy or "wedge" $\mathrm{dt} t_{1} / \mathrm{d} p_{z}$ is only marginally higher than the $12 \%$ wage increase (as workers secure most of the subsidy through increased wages). The conservative estimates with the lowest supply elasticity and highest demand elasticity still imply substantive deadweight losses, accumulating to around $2 \%$ of the total output covered in science park policies, or around $10 \%$ of the productivity benefits of the policy. Midrange estimates imply that the deadweight loss is around a quarter of policy's productivity benefits. The worst-case scenarios exhibits unrealistically large implicit labor-related subsidies that exceed unity (i.e., a policy that more than compensates the wage bill).

The deadweight losses due to labor displacement seem comparable to related studies on U.S. place-based policies. ${ }^{13}$ Busso et al. (2013) do the exercise most related to ours; they find labor displacement welfare costs of $13-18 \%$ of the flow cost of the subsidy. Translating this to our comparison (which is relative to output, not to the policy costs) requires a back-of-the-envelope calculation. Their worst-case scenario is a welfare loss of a $\$ 9.7$ million relative to an $\$ 800$ million wage bill. When using the United States economy labor cost share in output of around $67 \%$, the welfare cost due to labor displacement translates to roughly $2 \%$ relative to output covered by the policy. This is roughly similar to our lower bound estimates (supply elasticity 0.3 and demand elasticity 0.5 ). The $19 \%$ implicit labor subsidy in those estimates also corresponds to the $20 \%$ ad valorem labor subsidy studied in Busso et al. (2013). The resemblance is not entirely surprising, as the studies compare closely in terms of the elasticity of employment to policy designation; and the labor costs shares from our estimates are not far from the United States economy (around 0.59). However, at labor supply elasticities that represent the United States economy better (0.86, Table 5, second panel), our estimates suggest about twice the displacement costs that Busso et al. (2013) find. The cause could be that at those elasticities, Chinese firms retain much of the policy benefits, and the implied wedges are large. Intuitively, one might expect larger labor market distortion of the Chinese policy, because (a) Chinese workers have poorer bargaining positions and higher substitutability (Hsing, 2010) and (b) high-tech industries in China are much more labor-intensive than high-tech industries in many Western countries (Baltagi, Egger, \& Kesina, 2016).

\section{6 | SENSITIVITY ANALYSIS}

We have argued that the estimated productivity and wage effects may be interpreted as a causal effect of placebased policies. In this section, we summarize the main robustness checks, which are discussed in full length in Online Appendix C.

In Online Appendix C.1 we first consider an alternative identification strategy using local industrial parks as control areas instead of locations close to science park boundaries. A similar approach has been used by Wang (2013) and Busso et al. (2013) who also use "runner-up" locations as a counterfactual. If the upgrading of local parks into science parks is random over time we measure a causal impact of science parks on productivity. We then proceed with the use of an alternative measure of productivity based on value added in Online Appendix C.2, leading to similar results.

\footnotetext{
${ }^{13}$ Although the estimates of displacement magnitudes vary throughout the literature (Neumark \& Simpson, 2015).
} 
We examine in Online Appendix C.3 whether the presence of agglomeration economies, proxied by firm density, may provide an explanation for the productivity effect. As shown in Appendix A.1 the welfare implications may be somewhat different if agglomeration economies are an important driver of the productivity effect. However, we do not find evidence that agglomeration economies that drift across the science park boundaries are important. The quality of Chinese national data has been criticized, as they may reflect politicized aggregations of data submitted by local and other statistical bureaus (Au \& Henderson, 2006). Online Appendix C.4 therefore uses another (cross-sectional) data set to corroborate our results and investigates whether the omission of information on land use matters for the results.

In the current analysis we analyze the effect of science park policies using spatial and temporal differencing. More specifically, we compare the productivity changes between a firm that is in a science park with a firm that is just across the border of a science park. It is therefore unlikely that the comparison of nearby companies along the science park boundary is confounded by selection of companies due to shocks to their future prospects to innovate and productivity. For example, a firm may come up with a portfolio of more promising innovative projects than a rival company, so that the latter firm is not allowed to locate in a science park. In the preferred specifications, we identify the effect based on stayers, so we think that unobserved shocks to firms' productivities are unlikely to play a major role. Nevertheless, we could include firm-specific linear trends, so that we identify the effect of science parks based on nonlinear changes in productivity. In Online Appendix C.5 we investigate whether the inclusion of firm-specific linear trends affect the main results. It appears that the point estimates are similar, although they are imprecise because we include so many additional variables.

Online Appendix C.6 pays attention to treatment heterogeneity. First, we investigate whether the effect of science park policies is different for domestic and foreign-owned firms. We do not find robust evidence for treatment heterogeneity. Then, we show that there is no difference in the treatment effect between high-tech and low-tech firms.

In Online Appendix C.7 we check whether our results can be explained by differences in tax regimes. We continue with testing and relaxing the assumptions made in the spatial differencing estimation strategy in Online Appendix C.8. Finally in Online Appendix C.9, we test the robustness of the results by deliberately ignoring measurement error, through the inclusion of observations from neighborhoods that are partly in science parks.

Online Appendix C.10 studies whether anticipation and adjustment effects are important. Although confidence bands are wide, it seems that anticipation and adjustment effects are not important, which confirms the assumption that science park effects are immediate and permanent.

\section{CONCLUSIONS AND DISCUSSION}

In this paper, we analyze the economic impact of place-based governmental investments in science parks in the metropolitan area of Shenzhen (China). Virtually all of the empirical studies on place-based policies traditionally examine programs for deprived areas in developed economies. However, the welfare arguments may be different when applied to place-based policies in leading areas of developing and transition economies. We argue that especially in China, institutional circumstances, pronounced demographic and economic transitions, and a substantial rural-urban migration, enabled the application of placed-based policies in the form of science parks and special economic zones in cities on scales that are unprecedented in Western economies (Wei, 2000; Wu \& Gaubatz, 2013). These policies might stimulate relatively productive firms and people and foster positive spillovers rather than reinforcing negative spillovers, as is often observed in Western countries.

We note that place-based policies can have large welfare costs depending on the responses of the people and places that the policies are applied to. As a result, the welfare costs or deadweight losses of such programs can be approximated by interpreting local economy's responses to such a program. We contribute to the discussion on the effectiveness of place-based interventions in three ways. First, we introduce a theoretical model in which welfare 
gains and losses, productivity, wages, and employment are simultaneously introduced and measured in relation to each other. This stylized model informs us of the magnitude of the displacement effects and potential deadweight losses of the localized policies. Second, we empirically test the effectiveness of place-based development strategies on firm-level productivity by focusing on science park development in Shenzhen, China while controlling for observed and unobserved heterogeneity, sorting, and selection. This approach enables us to distinguish causal impacts of the policies from several confounding explanations of productivity differences. Third, we contribute to the understanding of important differences in the role of place-based policies in developed countries on the one hand, and transition countries on the other hand. While almost unstudied, China, India, Brazil, South Africa, Russia, and many other transition countries extensively use place-based policies, science parks, and special economic zones to promote development (Frick et al., 2018). The empirical evidence to date is therefore arguably not representative of many of the place-based policies that are in place worldwide.

Our results show that area-based incentives have a substantial impact on firms' productivity in Shenzhen's science parks. If we include firm fixed effects and use spatial differencing, firms' output has increased by $15-25 \%$ due to science park policies. These large and economically meaningful effects are in line with the findings of Wang (2013) and Zheng et al. (2017) and contribute to the idea that place-based policies have much more profound effects when governments invest in leading rather than lagging regions. We subject our results to an extensive sensitivity analysis, including an analysis based on another identification strategy and a (cross-sectional) data set. We also test the impact of science parks on wages and employment. We find positive causal effects of the policies on wages. We also find weak evidence that firms have hired more people due to the science park policies. Using a stylized theoretical model, we estimate that the displacement effects on the labor market are considerable. The deadweight loss estimates range between $10 \%$ and $40 \%$ of the productivity benefits of the policy, depending on the relevant labor demand elasticities. This result suggests that place-based policies may have substantial distortive impacts on local economies.

These outcomes are important for determining the effectiveness of place-based policy strategies in emerging and developing countries. The welfare and productivity effects in science parks can be remarkably large, as shown in our research. Yet, this does not mean it should be unambiguously promoted elsewhere: they could inhibit decline in nearby regions and their effectiveness could strongly depend on the local context (Frick et al., 2018). Policy efforts for continued investment and productive impact of science parks may not suffice for balanced economic development: our analyses also show that science parks may lead to displacement effects on labor that are large compared with many previous studies. Place-based policies may therefore help the development of the designated areas while hampering productive development nearby. This does not imply that policy programs did not succeed, as the spatial impacts of such policies could be motivated by redistribution (Neumark \& Simpson, 2015, p. 1225). Yet, when policy is not deliberately focused on relocation, it should be noted that the unintended costs may be high. Although research in western contexts generally confirms the occurrence of displacement (Papke, 1993), our study shows that the magnitude of displacement costs may be much higher in emerging economies. In particular, our study may form an example of a location where worker's responses to policies are strong, leading to large associated distortions of the policy. The large costs uncovered in the context of our study warrant more research on policy-driven displacements.

\section{ACKNOWLEDGEMENTS}

We thank Maximilian von Ehrlich, Aart Gerritsen, Martijn Kobus, Jos van Ommeren as well as participants of seminars in Washington D.C., Rome (CERUP), Rotterdam and Amsterdam, for comments. Koster: This study has benefited from a VENI research grant from the Netherlands Organisation for Scientific Research. 


\section{ORCID}

Michiel Gerritse (D) http://orcid.org/0000-0001-6327-5456

Frank G. Oort (iD) http://orcid.org/0000-0003-0614-768X

\section{REFERENCES}

Alder, S., Shao, L., \& Zilibotti, F. (2016). Economic reforms and industrial policy in a panel of Chinese cities. Journal of Economic Growth, 21(4), 305-349.

Au, C. C., \& Henderson, J. V. (2006). Are Chinese cities too small? Review of Economic Studies, 73(3), 549-576.

Baltagi, B. H., Egger, P. H., \& Kesina, M. (2016). Firm-level productivity spillovers in China's chemical industry: A spatial Hausman-Taylor Approach. Journal of Applied Econometrics, 31(1), 214-248.

Barca, F., McCann, P., \& Rodríguez-Pose, A. (2012). The case for regional development intervention: Place-based versus place-neutral approaches. Journal of Regional Science, 52(1), 134-152.

Bayer, P., Ferreira, F., \& McMillan, R. (2007). A unified framework for measuring preferences for schools and neighborhoods. Journal of Political Economy, 115(4), 588-638.

Black, S. E. (1999). Do better schools matter? Parental valuation of elementary education. Quarterly Journal of Economics, 114(2), 577-599.

Busso, M., Gregory, J., \& Kline, P. (2013). Assessing the incidence and efficiency of a prominent place based policy. American Economic Review, 103(2), 897-947.

Chaurey, R. (2013). Location based tax incentives: Evidence from India. New York, NY: Mimeograph, Columbia University.

Chen, B., Li, Y., \& Yin, Y. (2016). FDI, industry heterogeneity and employment elasticity in China. Review of Development Economics, 20(1), 189-200.

Cheng, F., Van oort, F., Geertman, S., \& Hooimeijer, P. (2014). Science park planning and the co-location of high-tech smalland medium sized firms in China's shenzhen. Urban Studies, 51(5), 1073-1089.

Cheshire, P. C., Nathan, M., \& Overman, H. G. (2014). Urban economics and urban policy: Challenging conventional policy wisdom. Cheltenham: Edward Elgar Publishing.

Chetty, R. (2009). Sufficient statistics for welfare analysis: a bridge between structural and reduced-form methods. Annual Review of Economics, 1(1), 451-488.

Chetty, R., Guren, A., Manoli, D., \& Weber, A. (2013). Does indivisible labor explain the difference between micro and macro elasticities? A meta-analysis of extensive margin elasticities. NBER Macroeconomics Annual, 27(1), 1-56.

Einiö, E., \& Overman, H. G. (2012). The effects of spatially targeted enterprise initiatives: Evidence from UK LEGI. Mimeo, London School of Economics.

Enright, M. J., Scott, E., \& Chang, K.-M. (2005). Regional powerhouse: The greater Pearl River Delta and the rise of China. Singapore: Wiley.

Fleisher, B. M., \& Wang, X. (2004). Skill differentials, return to schooling, and market segmentation in a transition economy: The case of mainland China. Journal of Development Economics, 73(1), 315-328.

Foray, D. (2014). Smart specialisation. Opportunities and challenges for regional innovation policy. London: Routledge.

Foster-McGregor, N., Poeschl, J., \& Stehrer, R. (2016). Offshoring and the elasticity of labor demand. Open Economies Review, 27(3), 515-540.

Frick, S. A., Rodríguez-Pose, A., \& Wong, M. D. (2018). Towards economically dynamic special economic zones in emerging countries. Economic Geography. Forthcoming.

Garretsen, H., McCann, P., Martin, R., \& Tyler, P. (2013). The future of regional policy. Cambridge Journal of Regions, Economy and Society, 6, 179-186.

Glaeser, E. L. (2008). Cities, agglomeration, and spatial equilibrium. Oxford: Oxford University Press.

Glaeser, E. L., Kallal, H. D., Scheinkman, J. A., \& Shleifer, A. (1992). Growth in cities. Journal of Political Economy, 100(6), 1126-1152.

Gobillon, L., Magnac, T., \& Selod, H. (2012). Do unemployed workers benefit from enterprise zones? the french experience. Journal of Public Economics, 96(9-10), 881-892.

Greenstone, M., Hornbeck, R., \& Moretti, E. (2010). Identifying agglomeration spillovers: evidence from winners and losers of large plant openings. Journal of Political Economy, 118(3), 536-598.

Hahn, J., Todd, P., \& Klaauw, W. (2001). Identification and estimation of treatment effects with a regression-discontinuity design. Econometrica, 69(1), 201-209.

Hsing, Y.-T. (2010). The great urban transformation: Politics of land and property in China. Oxford: Oxford University Press.

Hu, J.-L., Han, T.-F., Yeh, F.-Y., \& Lu, C.-L. (2010). Efficiency of science and technology industrial parks in China. Journal of Management Research, 10(3), 151-166. 
Imbens, G. W., \& Lemieux, T. (2008). Regression discontinuity designs: A guide to practice. Journal of Econometrics, 142(2), 615-635.

Kline, P. (2010). Place-based policies, heterogeneity, and agglomeration. American Economic Review, 100(2), $383-387$.

Kline, P., \& Moretti, E. (2013). Place-based policies with unemployment. American Economic Review, 103(3), $238-243$.

Koster, H. R. A., van Ommeren, J., \& Rietveld, P. (2014). Agglomeration economies and productivity: A structural estimation approach using commercial rents. Economica, 81(321), 63-85.

Lai, H. C., \& Shyu, J. Z. (2005). A comparison of innovation capacity at science parks across the taiwan strait: The case of Zhangjiang High-Tech Park and Hsinchu science-based industrial park. Technovation, 25, 805-813.

Lichter, A., Peichl, A., \& Siegloch, S. (2015). The own-wage elasticity of labor demand: A meta-regression analysis. European Economic Review, 80, 94-119.

Linden, G., Kraemer, K. L., \& Dedrick, J. (2009). Who captures value in a global innovation network? Communications of the ACM, 52(3), 140.

Lucas, R. E., \& Rossi-Hansberg, E. (2002). On the internal structure of cities. Econometrica, 70(4), 1445-1476.

MacDonald, S., \& Deng, Y. (2004). Science parks in China: A Cautionary exploration. Journal of Technology, Intelligence and Planning, 1, 1-14.

McCann, P., \& Ortega-Argilés, R. (2013). Smart specialization, regional growth and applications to European Union Cohesion Policy. Regional Studies, 1-12.

Moretti, E. (2004). Workers' education, spillovers, and productivity: evidence from plant-level production functions. American Economic Review, 94(3), 656-690.

Neumark, D., \& Simpson, H. (2015). Place-based policies. In Duranton, G., Henderson, J. V., \& Strange, W. C. (Eds.), Handbook of regional and urban economics (5). Amsterdam: Elsevier.

Ng, M. K. (2003). Shenzhen. Cities, 20(6), 429-441.

Papke, L. E. (1993). What do we know about enterprise zones? Tax Policy Economics, 7, 37-72.

Rodríguez-Pose, A., \& Hardy, D. (2014). Technology and industrial parks in emerging economies. Panacea or pipedream. Berlin: Springer.

Shenzhen Bureau of Trade and Industry (2001). Guidance on transforming traditional industries with high-tech or advanced applicable technologies. Shenzhen: Shenzhen Bureau of Trade and Industry.

Shenzhen Planning Bureau (2006). Transformation and Evolution. Shenzhen: Shenzhen Bureau of Trade and Industry.

Wang, J. (2013). The economic impact of special economic zones: Evidence from Chinese municipalities. Journal of Development Economics, 101(1), 133-147.

Wei, X. (2000). Acquisition of technological capability through special econopmic zones (SEZs): The case of Shenzhen. Industry and Innovation, 7(2), 199-221.

Wu, W., \& Gaubatz, P. (2013). The Chinese city. London: Routledge.

Yeung, Y., Lee, J., \& Kee, G. (2009). China's special economic zones at 30. Eurasian Geography and Economics, 50(2), $222-240$.

Zeng, D. Z. (2015). Global experiences with special economic zones-With a focus on China and Africa. Washington D.C

Zeng, D. Z. (2010). How do special economic zones and industrial clusters drive China's rapid development? In Zeng, D. Z. (Ed.), Building Engines of Growth and Competitiveness in China. Experience with Special Economic Zones and Industrial Clusters. Washington D.C: World Bank.

Zheng, S., Sun, W., Wu, J., \& Kahn, M. E. (2015). The birth of edge cities in China: Measuring the spillover effects of industrial parks. Journal of Urban Economics, 100, 80-103.

\section{SUPPORTING INFORMATION}

Additional supporting information may be found online in the Supporting Information section at the end of the article.

How to cite this article: Koster HR, Cheng FF, Gerritse M and van Oort FG. Place-based policies, firm productivity, and displacement effects: Evidence from Shenzhen, China. J Regional Sci. 2018;1-27.

https://doi.org/10.1111/jors.12415 


\section{APPENDIX: EXTENSIONS TO THE THEORETICAL FRAMEWORK}

\section{Place-based policies and agglomeration externalities}

One objection to the use of factor employment changes in welfare measures is that there may be positive externalities, especially agglomeration externalities. These externalities potentially bias the welfare conclusions. Suppose that the multiplicative technology $A_{1}$ is taken as given by producers, but it effectively depends on regional employment: $Q_{1}=A_{1}\left(L_{1}, T_{1}\right) \cdot f\left(K_{1}, L_{1}\right)$. The first-order derivative with respect to welfare is then the sum of the displacement effect and the externality:

$$
-t_{1} w_{1} \frac{\mathrm{d} \ell_{1}}{\mathrm{~d} t_{1}}+\sum_{z} \frac{q_{z}}{A_{z}} \frac{\partial A_{z}}{\partial \ell_{z}} \frac{\mathrm{d} \ell_{z}}{\mathrm{~d} t_{1}}
$$

The latter term is the agglomeration effect due to labor reallocation in all regions $z$. For the moment, we will assume that the net effect can be positive if the policy concentrates workers in agglomerated areas - intuitively, moving one worker from a small region to a large, more productive region increases the net agglomeration benefit. The rate at which an average worker moving to region 1 changes aggregate productivity is his gain in region 1 minus the agglomeration benefits lost in an average origin location $\left(z^{-1}\right)$ :

$$
\psi_{\ell}=\frac{q_{1}}{A_{1}} \frac{\partial A_{1}}{\partial \ell_{1}}+\sum_{z^{-1}} \frac{q_{z}}{A_{z}} \frac{\partial A_{z}}{\partial \ell_{z}} \frac{\mathrm{d} \ell_{z} / \mathrm{d} t_{1}}{\mathrm{~d} \ell_{1} / \mathrm{d} t_{1}}
$$

Suppose that the cost share of labor is $\alpha_{\ell}$ (in our empirical specification, this is the Cobb-Douglas parameter for labor). Multiplying and dividing by $t_{1}$ and $L_{1}$ and using the definition gives an expression of the welfare change as:

$$
-w_{1} e_{1} \frac{\mathrm{d} \ell_{1}}{\mathrm{~d} t_{1}} \frac{t_{1}}{\ell_{1}}\left(1-\frac{\psi_{e}}{t_{1} w_{1}}\right)
$$

where $\psi_{\ell}$ is the average agglomeration benefit per moving worker, and $t_{1} w_{1}$ is the per worker subsidy cost. High agglomeration benefits relative to the subsidy can diminish the welfare loss or even turn it into a gain. Thus, with agglomeration externalities, an estimate of the welfare costs could be overstated, or the welfare effect could even be interpreted as a loss when there is a net positive effect.

In our methodology, agglomeration effects are unlikely to influence our estimates of displacement. The reason is that we compare firms that are close to science park borders that have no substantial barriers in terms of infrastructure or geography. Therefore, any agglomeration effects due to firm density are comparable between firms just inside and just outside the science park border. Hence, they should impact the treatment and control groups alike. To verify this in the data, we investigate agglomeration externalities by incorporating access measures to the other firms in the area-they do not matter for our estimates of the science park effect. See Online Appendix C.3 for more details.

\section{Place-based policies and heterogeneous labor}

Our baseline model is restricted to a single type of labor. It is plausible that labor quality is heterogeneous. To study the ramifications for our framework, suppose we allow labor to have heterogeneous productivity, indexed by the worker index $i$. Assume that worker productivity is observable. The first-order condition of firm $j$ for hiring worker $i$ is now $d q_{j z d} / d e_{j z}\left(a_{i}\right)=w_{j z i}\left(1-t_{z}\right)$. The wage is now worker-firm-specific. Profits are $\max _{\ell, k} \pi_{j z}=q_{j z}-\left(1-t_{z}\right) \int w_{j z i} \ell_{i j z} d(i \in j)-r\left(1-s_{z}\right) k_{j z}$, where we use $i \in j$ as shorthand notation for all workers $i$ used in firm $j$. Using this, welfare is now written as: 


$$
\begin{aligned}
W= & \int\left(w_{i j z}+\xi_{i z}\right) d i+\int \pi_{j z} d j+r\left(K_{1}+K_{2}\right)-\int t_{1} w_{j z i} \ell_{j} d(i \in z=1) \\
& -\int s_{1} r k_{j 1} d j-T\left(Q_{1}, A_{1}\right),
\end{aligned}
$$

where $\int t_{1} w_{j z i} \ell_{j} \mathrm{~d}(i \in z=1)$ is the subsidy disbursed to firms employing workers in the science park. Following the derivation in Section 2 , the gross relative welfare effect becomes:

$$
\Delta \mathcal{R} W=e_{A} \frac{d A_{1} / d p_{1}}{A_{1}}-\int \alpha_{\ell i} e_{\ell i} \mathrm{di} \frac{d t_{1}}{\mathrm{~d} p_{1}}-\alpha_{k} e_{k} \frac{d s_{1}}{\mathrm{~d} p_{1}}
$$

where $\alpha_{\ell \mathrm{i}}=\left(\mathrm{w}_{\mathrm{jzi}} \ell_{\mathrm{i}}\right) / Q_{1}$ is the worker-specific cost share and $e_{\ell \mathrm{i}}=\left(d \ell_{1 i} / d t_{1}\right)\left(t_{1} / \ell_{i}\right)$ is the worker-specific elasticity of labor supply in the science park area in response to the policy. The term $\int \alpha_{\ell i} e_{\ell_{i}}$ di replaces $\alpha_{\ell} e_{\ell}$ based on representative workers in the main text. In both cases, the deadweight loss on the labor market scales to the wage bill (scaled to output), because the government provides an ad-valorem subsidy. In terms of welfare estimates, the average employment responses weighted by the labor cost share may overstate the dead-weight losses if the workers that represent high labor costs shares (i.e. the most productive workers) are, in fact, unresponsive. Given the similar relative distribution of highly educated workers over areas just inside and outside science parks (see Online Appendix C.4), those differences are likely minor. 